\title{
The structure and function of Alzheimer's gamma secretase enzyme complex
}

Sudarsan Krishnaswamy ${ }^{1}$, Giuseppe Verdile ${ }^{1,2,3}$, David Groth ${ }^{1,3,4}$, Limbikani Kaneyenda ${ }^{1}$, and Ralph N Martins ${ }^{1,2,3}$.

${ }^{1}$ Centre of Excellence for Alzheimer's Disease Research and Care, School of Exercise, Biomedical and Health Sciences, Edith Cowan University, Joondalup, WA, Australia. ${ }^{2}$ School of Psychiatry and Clinical Neurosciences, University of Western Australia, Crawley, WA, Australia. ${ }^{3}$ Sir James McCusker Alzheimer's Disease Research Unit, Hollywood Private Hospital, Nedlands, WA, Australia. ${ }^{4}$ Curtin Health Innovation Research Institute, Western Australian Biomedical Research Institute, Curtin University, Bentley, WA, Australia.

Corresponding Author: Professor Ralph Martins

Centre of Excellence for Alzheimer's disease Research and Care, School of Exercise, Biomedical and Health Sciences

Edith Cowan University,

PH: +61 863045456

FAX: +61 863045851

Email: r.martins@ecu.edu.au

Running head: Structure and function of gamma secretase. 


\section{ABSTRACT}

The production and accumulation of the beta amyloid protein (A $\beta$ ) is a key event in the cascade of oxidative and inflammatory processes that characterises Alzheimer's disease. A multi-subunit enzyme complex, referred to as gamma secretase, plays a pivotal role in the generation of $A \beta$ from its parent molecule, the amyloid precursor protein (APP). Four core components (presenilin, nicastrin aph-1 and pen-2) interact in a high molecular weight complex to perform intramembrane proteolysis on a number of membrane bound proteins, including APP and Notch. Inhibitors and modulators of this enzyme have been assessed for their therapeutic benefit in AD. However, though these agents reduce $\mathrm{A} \beta$ levels, the majority have been shown to have severe side-effects in pre-clinical animal studies, most likely due to its role at processing other proteins involved in normal cellular function. Current research is directed at a greater understanding of this enzyme in particular elucidating the roles that each of the core proteins play in its function. In addition, a number of interacting proteins that are not components of $\gamma$-secretase also appear to play important roles in modulating enzyme activity. This review will discuss the structural and functional complexity of the gamma secretase enzyme and the effects of inhibiting its activity.

Keywords: Alzheimer's disease, amyloid precursor protein, Anterior pharynx defective homolog 1, beta amyloid, gamma secretase, Notch receptor, presenilins, nicastrin, , presenilin enhnacer-2, Regulated intramembrane proteolysis

Abbreviations: AD, Alzheimer's disease; FAD, Familial Alzheimer's disease; EOAD, Early onset Alzheimer's disease; A $\boldsymbol{\beta}$ Amyloid beta; APP, Amyloid precursor protein; APLP, Amyloid precursor like protein; PS1 Presenilin 1; PS2 - Presenilin 2; NCT Nicastrin; Aph-1, Anterior pharynx defective homolog 1; Pen-2, Presenilin enhancer 2; BACE, Beta-site APPcleaving enzyme; ICD, Intra cellular domain; AICD, Amyloid precursor protein intra cellular domain; NICD, Notch intra cellular domain; NECD, Notch extracellular domain; CICD, Cadheren intracellular domain; RIP, Regulated intramembrane proteolysis; LRP, Lipo protein receptor related protein; SREBP, Sterol regulatory element binding protein; IRE, Interferon response element; ATF, Activated transcription factor; CTF, C-terminal fragment; TMD, Transmembrane domain; NTF, N-terminal fragment; SPP, Signal peptide peptidase; NSAIDs, Non-steroidal anti-inflammatory drugs; NMDA, N-methyl D-Aspartate; GSI, Gamma secretase inhibitors; GSM, Gamma secretase modulators; LDL, Low density lipoprotein; VLDL, Very low density lipoprotein; IGF - Insulin like growth factor 


\section{INTRODUCTION}

Alzheimer's disease (AD) is a complex, progressive neurodegenerative disorder that is neuropathologically characterised by extensive neuronal loss and the presence of neurofibrillary tangles and senile plaques. While the majority of AD cases are sporadic, $~ 5 \%$ of $\mathrm{AD}$ cases are familial (FAD) with mutations in three genes, amyloid precursor protein, presenilin 1 (PS1) and presenilin 2 (PS2) accounting for the majority of cases. A major feature of both sporadic and familial forms of $\mathrm{AD}$, is the accumulation and deposition of a small peptide referred to as beta amyloid $(\mathrm{A} \beta)$ within brain tissue of $\mathrm{AD}$ sufferers. The mechanisms that underlie the disease processes are poorly understood. However, the accumulation of $A \beta$ is thought to play a pivotal role in neuronal loss or dysfunction through a cascade of events that include the generation of free radicals, mitochondrial oxidative damage and inflammatory processes (reviewed in Refs. ${ }^{1,2}$ ). One of the primary events that results in the abnormal accumulation of $A \beta$ is thought to be the dysregulated proteolytic processing of its parent molecule, the amyloid precursor protein (APP).

The APP molecule is a transmembrane glycoprotein that is proteolytically processed by two competing pathways, the non-amyloidogenic and amyloidogenic (A $\beta$ forming) pathways (Figure 1). How these pathways are regulated remains unclear. However, there are many factors including diet, hormonal status, and genetic mutations that influence the processing of APP to generate A $\beta$ (reviewed in Refs. ${ }^{3,4}$ ). Three major secretases are postulated to be involved in the proteolytic cleavage of APP. These include $\alpha$-secretase [of which the metalloproteases ADAM17/ TACE and ADAM 10 are likely candidates], beta APP cleaving enzyme [BACE, formally known as $\beta$-secretase] and the $\gamma$-secretase. The $\alpha$ secretase cleaves within the A $\beta$ domain of APP thus precluding the formation $A \beta$ and generating non-amyloidogenic fragments and a secreted form of APP ( $\alpha$-APPs). In the amyloidogenic pathway, BACE cleaves near the N-terminus of the A $\beta$ domain on the APP molecule, liberating another soluble form of APP, $\beta$-APPs and a C-terminal fragment (C99) containing the whole $A \beta$ domain. The final step in the amyloidogenic pathway is the intramembranous cleavage of the C99 fragment by $\gamma$-secretase, to liberate the A $\beta$ peptide (reviewed in Ref. ${ }^{1}$ ). 
Two additional cleavage sites on the APP-C terminal fragment have been identified and termed the $\varepsilon$-cleavage site and $\zeta$-cleavage site. The $\varepsilon$-cleavage site occurs 7-9 residues distal to the $\gamma$-secretase cleavage site at A $\beta 40 / 42$, generating the APP intracellular domain (AICD) ${ }^{5-8}$. The AICD has been reported to bind to different proteins and may be involved in several intracellular pathways, including apoptosis, neuronal growth and regulation of gene expression (reviewed in ${ }^{9}$ ). It is interesting that the $\varepsilon$-secretase site is equivalent to the S3 site of the Notch receptor ${ }^{10}$ liberating the intracellular domain of Notch (NICD), which like AICD translocates to the nucleus and activates target gene expression (see below for more discussion of Notch processing). These findings suggest that cleavage at the $\varepsilon$-site may be a common event for the processing of type I transmembrane proteins cleaved by $\gamma$-secretase, to liberate fragments involved in cell signalling. Recently, an additional A $\beta$ fragment, referred to as $A \beta 46$ has been identified ${ }^{11-13}$. This fragment, unlike $A \beta 40 / 42$ is exclusively intracellular and has not been shown to be secreted from the cell. The pathological relevance of this longer form of $A \beta$ is unknown, however known inhibitors of $\gamma$-secretase that reduce A $\beta 40 / 42$ production, lead to an intracellular accumulation of the potentially pathological $\mathrm{A} \beta 46^{11,13}$ which is important to consider when developing agents that target $\mathrm{A} \beta 42$ production.

The finding of additional $A \beta$ fragments $(A \beta 37,38$ or 39$)$ in cells and brain homogenates from humans and transgenic mice and the identification of additional cleavage sites may suggest that there are multiple $\gamma$-secretase enzymes (further discussion below). However, one model proposed by Zhao et al., ${ }^{13}$ suggests a single $\gamma$-secretase enzyme with a broad range of activity, performing multiple cleavages sequentially along the APP-C99 fragment. In this model, (Figure 2) the APP-C99 fragment is first cleaved at the $\varepsilon$-site (A $\beta 49)$ and then undergoes further cleavage at the $\zeta$-site to generate $A \beta 46$. Additional cleavage of this fragment into $A \beta 43$ can occur, which is then processed further into $A \beta 40$ followed by additional cleavage liberating $A \beta 37$. Alternatively, $A \beta 46$ can be cleaved into $A \beta 42$, which is processed further into $A \beta 38 / 39$. Evidence for a single $\gamma$-secretase moiety is provided by the observation that a number of inhibitors of this enzyme reduce the levels of all $A \beta$ species. However, the single catalytic site model inadequately explains the concurrent production of the major $A \beta 40$ and $A \beta 42$ species. In addition, this model doesn't explain the observations that Non-steroid anti-inflammatory drugs, target A $\beta 42$ specifically without altering NICD or 
AICD production, and that some $\gamma$-secretase inhibitors reduce $A \beta 40$ or $A \beta 42$ production but not $A \beta 46$ levels. Although it has been suggested that a single enzyme could possess two catalytic sites ${ }^{13}$ it however doesn't rule out multiple $\gamma$-secretase enzymes or other proteases with $\gamma$-secretase activity existing.

\section{THE $\gamma$-SECRETASE ENZYME: STRUCTURE, ASSEMBLY AND POSTULATED FUNCTION OF ITS COMPONENTS.}

\section{Structure}

The $\gamma$-secretase enzyme is thought to be an aspartyl protease that has the unusual ability to regulate intramembrane proteolysis (RIP) for a growing list of type 1 integral membrane proteins which include, APP, APP like proteins (APLPs), E-Cadherin, CD44, lipoprotein receptor related protein (LRP), Notch, sterol regulatory element -binding protein (SREBP), interferon response element (IRE1) and activated transcription factor 6 (ATF-6) (for recent review see ${ }^{14}$ ). The mechanism of RIP and $\gamma$-secretase activity is unknown. However a transient hydrophilic environment for catalysis within the lipid membrane must be created. Furthermore, the enzyme (or an enzyme domain) must have the ability to bend and unwind the $\alpha$-helical substrates, exposing their amide bonds to hydrolysis. Therefore it is conceivable that the $\gamma$-secretase enzyme is an integral protein of the lipid bi-layer and contains a number of proteins that may have different functions within an enzyme complex. The exact conformation or molecular architecture of the $\gamma$-secretase enzyme remains unclear. However, large molecular mass complexes of $\sim 250 \mathrm{kDa}{ }^{15,16} \sim 500 \mathrm{kDa}{ }^{17-21}$ and $\sim 2000 \mathrm{kDa}{ }^{17,22}$ have been identified.

Over the last few years biochemical and genetic approaches have identified four components of the $\gamma$-secretase complex, presenilins, nicastrin, anterior pharynx defective (aph-1) and presenilin enhancer 2 (pen-2). Over-expression and expression knockdown studies have provided strong evidence that these proteins are essential for $\gamma$-secretase activity 19,23-28. Subsequent reconstitution studies in non-mammalian cells have provided evidence that these are the only components responsible for $\gamma$-secretase catalytic activity ${ }^{29-31}$. Presenilins are nine-pass transmembrane proteins and considered to possess enzyme catalytic activity. Nicastrin is a single pass membrane protein with a large ectodomain that is heavily 
glycosylated which plays a vital role in $\gamma$-secretase assembly. Aph-1 occurs as a seven-pass transmembrane protein that exists in two homologous forms, located on chromosome 1 and chromosome 15 (aph-1a \& aph-1b) respectively; ${ }^{23}$. Aph-1a undergoes further splicing to generate a long and short isoform of aph-1a, with the short isoform more abundantly expressed in most tissues ${ }^{25}$. Aph-1 shares its function with nicastrin in forming the stable complex. The smallest component Pen-2 is a two-pass transmembrane protein that is thought to activate presenilin endoproteolysis ${ }^{27,32}$. Thus, overall the enzyme possesses 18 transmembrane domains making it difficult to elucidate the crystalline structure of the enzyme.

Structural analysis of the gamma secretase enzyme has mainly been through protein purification, visualisation using electron microscopy and analysis of particle images to provide a 3D- reconstruction of the purified complex ${ }^{33,34}$. These studies have revealed a globular structure for $\gamma$-secretase. The low-resolution 3D images of purified $\gamma$-secretase has revealed a central cavity with two low density regions and two openings indicating a possible existence of a substrate gating and releasing mechanism. How this may exist in a lipid environment remains to be determined. However, the active component and the active catalytic site of this enzymatic complex are yet to be identified. A clue as to how this may occur comes from successful crystallisation of a bacterial intramemebrane protease (GlpG). GlpG activity actually takes place in a V-shaped cavity separated from the lipid environment by six transmembrane domains ${ }^{35}$. More recently, the crystal structure of bacterial signal peptide peptidase (SPP) was determined ${ }^{36}$. The highly conserved SPP protease, performs intramembranous cleavage of type 2 transmembrane proteins and shares some similar characteristics to presenilins (discussed further below). The crystalline structure of the bacterial SPP showed a tetrameric structure, which is bowled shaped with an opening at its base of approximately $96 \AA ̊$ in diameter, predicted to be the membrane association surface. The ridge inside the bowel is restricted to 0 A concave surface creates the substrate binding pockets for four catalytic active sites within the tetramer structure. These structural studies with bacterial proteases have provided insight into high resolution structure and catalytic site of enzymes that perform intramembrane cleavage. Similar high resolution studies with the mammalian $\gamma$-secretase complex, although more difficult, are required to provide detail of the catalytic core of the $\gamma$-secretase complex. In addition, structure of the complex in the presence of lipids, to simulate the lipid membrane has not been established. 
Although several techniques can be used to provide structural information of membrane bound proteins, all of them suffer from notorious problems associated with handling membrane proteins. The proteins are adapted to the lipid bi-layer and tend to denature when extracted from the environment. The region of hydrophobic residues will need to be stabilised by detergents during preparation for structural analysis. High resolution $\mathrm{X}$ - ray crystallography methods have improved in which 3D crystallisation methods can be used. However, establishing the atomic structure of membrane protein is still risky as high resolution 3D crystals are required ${ }^{37}$. Nuclear magnetic resonance (NMR) is a structural analysis that doesn't require 3D crystals. However, this requires the membrane proteins to be solubilised, causing issues with protein stability ${ }^{37}$. An alternative technique is $2 \mathrm{D}$ electron crystallography, in which the protein is reconstituted into 2D crystals in the presence of lipids, thus providing the native environment for membrane bound proteins or complexes, such as $\gamma$-secretase.

\section{Assembly And Postulated Function Of The $\gamma$-Secretase Components.}

\section{Assembly of The $\gamma$-Secretase Complex.}

The core subunits of the $\gamma$-secretase enzyme are essential for the maturation and trafficking of the enzyme ${ }^{38,39}$. Interactions between the transmembrane domain of NCT and Aph1 play a significant role in the formation of the first stable sub-complex during the process of the active enzyme formation ${ }^{40}$. Evidence suggests that this interaction may occur very soon after APH-1 synthesis ${ }^{41}$ with the conserved GXXXG motif within transmembrane 4 of APH-1 important for this interaction ${ }^{42,43}$. This interaction has been shown to be independent of PS1 or PEN-2 as nicastrin mutants have been shown to restore APH-1 expression but not expression of the other components ${ }^{44}$. More recent evidence suggests that nicastrin is critical for the correct assembly of the $\gamma$-secretase complex within the endoplasmic reticulum and the intracellular trafficking of the complex to the cell surface ${ }^{45,46}$. It is thought that the presenilin holoprotein is then incorporated into the aph-1: NCT subcomplex, nicastrin undergoes post-translational modifications and the complex is transported to the cell surface (or other $A \beta$ generating compartments, i.e. TGN) as a trimeric complex. Pen-2 is then incorporated into the complex possibly through an interaction with presenilins with the "DYLSF" domain of pen-2 and a "NF" motif on transmembrane 4 of PS1 shown to 
be critical for the interaction between these proteins ${ }^{47-49}$. Ablation of pen-2 results in significantly reduced PS1 endoproteolysis and A $\beta$ production, suggesting that pen-2 is essential for the proteolytic cleavage of presenilins into the active components $19,23,26-28$. However, it is unclear whether pen-2 is the elusive protease responsible for this cleavage event. Once the presenilins are cleaved an active $\gamma$-secretase complex is formed.

\section{Function Of The Enzyme Components}

Evidence to date has suggested that the presenilins (PS1 and PS2) are the most critical component of the $\gamma$-secretase complex and maybe the catalytic component of this enzyme. Findings that mutations in PS1 account for the majority of inherited early onset forms of AD and result in the overproduction of the highly amyloidogenic $A \beta 42^{50-52}$ provided the initial evidence that PS1 facilitates $\gamma$-secretase activity. Subsequent studies provided evidence that presenilins may be the elusive $\gamma$-secretase enzyme. Many reports have shown that presenilin ablation or mutagenesis of two highly conserved aspartate residues within transmembrane domains 6 and 7 result in a reduction in $A \beta$ levels in vitro and in vivo ${ }^{53-56}$. Furthermore, aspartyl protease inhibitors and transition state analogue inhibitors designed to target the active site of the protease, all reduce $A \beta 40$ and $A \beta 42$ levels and have been shown to affinity label and bind to PS1 ${ }^{22,56,57}$. In addition, physical interactions between presenilins and $\gamma$ secretase substrates have been identified (reviewed in ${ }^{58}$ ). Although initial evidence strongly implicated presenilins in $\gamma$-secretase catalytic activity they do not exhibit typical aspartyl protease structural characteristics, in particular they lack the typical D(T/S)G motif required for the active site of an aspartyl protease. However, presenilins do contain the two aspartyl residues (eg: D257 and D385 for PS1) which are either critical for the active site on the $\gamma$ secretase complex or constitute the active site. The formation of this aspartyl catalytic site could result from one or multiple presenilin molecules. The full length PS1 protein is rapidly endoproteolytically cleaved within its characteristic large hydrophilic loop into amino- and carboxy-terminal fragments (NTF/CTF) of $\sim 27$ and $\sim 17 \mathrm{kDa}$, respectively ${ }^{59,60}$. These fragments are thought to interact with each other to form the catalytic component of $\gamma$ secretase ${ }^{61,62}$. The stoichiometry and the nature of the interaction between these fragments remain unclear. It has been shown by many studies that the NTF:CTF form a heterodimer in mammalian cells ${ }^{16,63-66}$ leading to suggestions that this heterodimer is the active $\gamma$-secretase 67. However, Cervantes and colleagues $2001{ }^{68}$ provided evidence that the presenilin fragments can form a tetramer by identifying heterodimers as well as NTF and CTF 
homodimers in yeast. Evidence for heterodimer and NTF homodimer (but not CTF homodimer) formation has been provided by photoaffinity labelled crosslinking studies ${ }^{69}$. This formation provides a core of aspartyl residues required for aspartyl protease activity. However, it has yet to be established wether the hypothetical "core" is formed between fragments from one PS1 molecule or multiple molecules within the complex.

Other proteases also share the unusual aspartyl motif GxGD and perform intramembranous cleavage of type I membrane proteins (reviewed in ${ }^{70}$ ). One such protease that has been widely studied due to its similar characteristics to presenilins are the signal peptide peptidases (SPPs). These proteases are members of a larger group of intramemebrane cleaving proteases (I-Clips) which have only a few endogenous substrates. They exist as monomers ${ }^{71}$ and homodimers ${ }^{72}$, however, the form that is actively involved in the cleavage process is still unclear. Although presenilins are to some extent similar to the SPPs, differences do occur. Presenilins mediate the cleavage of type I transmembrane proteins whereas SPPs process type 2 membrane proteins ${ }^{71}$. In contrast to presenilins, SPPs do not require interactions with other co-factors or undergo endoproteolysis for functional activity. Moreover, the topology of SPP is opposite to that of PS, such that, SPP cleaves transmembrane substrates with a membrane orientation opposite that of $\gamma$-secretase substrates ${ }^{73}$. Despite these differences the activities of presenilins and SPPs are similar.

The SPPs are evolutionarily conserved as they have been identified in Archea bacteria, Yeast plants and animals ${ }^{74}$. The amino acid sequence identity between human presenilin and SPPs is very low (20\%) ${ }^{74}$, however, they possess identical active site motifs YD, PAL and GXGD. Aspartate residues in the YD and GXGD sites are highly conserved and mutation of these residues abolishes the catalytic activity of both SPPs and presenilins ${ }^{71,75}$. $\gamma$-Secretase inhibitors that target presenilin- mediated activity also alter SPP activity, likewise some of the SPP inhibitors also suppress presenilin- mediated enzyme activity ${ }^{75,76}$. By showing that active site-directed $\gamma$-secretase inhibitors label the SPP homodimer, Nyborg and colleagues ${ }^{72}$ showed that the homodimer, rather than the monomer contains the active site. This is similar to presenilins where it has been proposed that dimerisation of the presenilin $\mathrm{N}$ and C-terminal fragments form the catalytic active GxGD site ${ }^{16,63-66}$. Isolating SPPs and presenilins from cell membranes and solubilising with detergent, Sato and colleagues ${ }^{75}$ showed that these proteins share certain biochemical properties. Both proteases have loose sequence specificity for substrates and recognise $\alpha$-helical regions of substrates 
and cleave within these regions. Inhibition of a substrate-based helical peptide that binds to a site distinct from the active site, suggests that binding of the substrate to the outer surface of the protease is an important initial step before entry into the water-containing active site. This is a likely mechanism of other membrane embedded proteases such as the S2P metalloproteases and the rhomboid family of serine protease and also a mechanism suggested for $\gamma$-secretase ${ }^{77}$. Recent evidence has suggested that like $\gamma$-secretase activity, SPPs cleaves the substrate at multiple sites within the TMD ${ }^{75,78}$ although the exact mechanism by which this occurs remains unknown for both SPP and $\gamma$-sectretase. Most surprisingly, the cleavage site specificity of SPP can be altered by certain non-steroidal anti-inflammatory drugs (NSAIDs) which are known to alter the cleavage of $\gamma$-secretase activity on APP ${ }^{79}$. The similarities and differences exhibited by SPP and $\gamma$-secretase could offer considerable insight into determining enzyme structure and developing novel inhibitors that target one enzyme over the other.

Apart from functioning in the assembly process of the $\gamma$-secretase complex, the core enzyme components have also other postulated functions. Evidence has shown that nicastrin is essential for the interaction between the complex and APP-C99 and thus may act as a receptor for $\gamma$-secretase substrates ${ }^{46,80}$. This suggests that nicastrin maybe a substrate docking site in addition to its role as a scaffold for building the active complex. Three dimensional electron microscopy studies have suggested similar conformation where nicastrin ectodomain and other regions (TM or HL) of the components may act as a plug that regulates the opening of the catalytic pore [reviewed in ${ }^{81}$ ].

Although aph-1 shares its function with nicastrin in the assembly and stabilisation of the $\gamma$-secretase complex, it may also be critical for the activity of the fully constructed $\gamma$ secretase complex. As well as binding to immature components of $\gamma$-secretase in early stages of complex formation, APH-1 also interacts with the mature forms of PS1, nicastrin and PEN-2 42,82. Furthermore, recent evidence suggests that this interaction occurs on the cell surface where it also binds the $\gamma$-secretase substrate, Notch and facilitates its cleavage ${ }^{82}$. Structural and functional similarities between aph-1 and other proteases that possess the ability for intramembranous cleavage (ie PS1, rhomboid), ${ }^{42,83}$ would suggest that this transmembrane protein might have an enzymatic function within the complex. However, aph1 sequence homology to known proteases and evidence for a role as a protease is currently lacking. 
Evidence suggests additional roles for pen- 2 within the $\gamma$-secretase complex. The Cterminal end of pen-2 has been shown to be important for $\gamma$-secretase activity since altering the length of the pen-2 C-terminus by addition or deletion of residues has been shown to reduce $A \beta 40$ and 42 generation without altering the binding of pen-2 to the complex ${ }^{47}$ suggesting that pen-2 may have an alternative function within the complex. One suggestion put forward by Hasegawa and colleagues ${ }^{47}$ is that the C-terminus of pen- 2 may be a linker/space molecule that maintains the spatial interactions between proteins within the complex. However, recent evidence using pen-2 C-terminal loss of function mutations suggest that the C-terminus acts as a "molecular clamp” holding together the presenilin fragments and the whole $\gamma$-secretase complex ${ }^{84}$. If this is the case, then pen- 2 is an integral part of the catalytic process holding the complex together whilst the $\gamma$-secretase products are generated.

Two additional proteins, TMP21 and CD147 have been shown to co-purify with the $\gamma$ scretase complex and modulate $\gamma$-secretase activity. TMP21 is a type 1 transmembrane protein and a member of a p24 cargo-family which may have a signalling role in the sorting and transport of proteins from the endoplasmic reticulum to the Golgi ${ }^{85,86}$. Chen and colleagues showed that TMP21 is a member of the complex as it was isolated in a high molecular weight presenilin complex, interacted with all of the known components of the $\gamma$ secretase complex, co-localised with the complex components in the ER, Golgi and cell surface and destabilised from the complex in the absence of the presenilins and pen-2. Although the over-expression of TMP21 did not alter $\gamma$-secretase activity, its suppression resulted in and increase in $A \beta 40$ and A $\beta 42$. However, suppression of TMP21 did not alter the production of AICD, Notch cleavage to generate NICD or cleavage of E-cadherin to generate CICD. These results are consistent with the notion that $\gamma$ - and $\varepsilon$ - secretase cleavage activities are independently regulated and indicate a role for TMP21 in modulating $\gamma$-secretase activity to generate A $\beta$. This role for TMP21 appears to be independent of its role in protein transport since the suppression of both TMP21and p24a (a member of the p24 cargo family that interacts with TMP21) does not result in additional increases in $A \beta$ production to that observed following the suppression of TMP21 only ${ }^{87}$. This finding led the authors to postulate that there are two pools of TMP21, a major pool that is stabilised by, p24a and has no role in $A \beta$ production and a minor pool that modulates $A \beta$ production, independent of 
p24a. Although, further investigation is required to determine the precise mechanism of action, it appears that TMP21 may function to regulate intramembrane proteolysis controlling $\gamma$-secretase activity and thus preventing the over-production of $A \beta$. This modulator role for TMP21 is important to consider when elucidating mechanisms on how $\gamma$-secretase activity is altered (for example by presenilin mutations) resulting in enhanced $A \beta 40$ and $A \beta 42$ production.

CD147 is a member of the immunoglobin superfamily that is involved in fetal development and retinal function as well as many other neurological processes such as development of the nervous system, involvement in spatial learning and recently in

modulating beta amyloid accumulation ${ }^{88,89}$. The mechanism by which CD147 modulates A $\beta$ accumulation is unclear, with two studies proposing different mechanisms of action. Zhou and colleagues (2005) ${ }^{88}$ showed that CD147 is possibly a regulatory component of the $\gamma$ secretase complex. In their study it was observed that CD147 depletion using RNA interference resulted in elevated $\mathrm{A} \beta 40 / 42$ production, without affecting expression levels of NCT, PEN-2, APH-1 and PS1 ${ }^{88}$. Vetrivel and colleagues however, showed that CD147 did not interact with the other $\gamma$-secretase complex components and concluded that it was not an integral part of the complex. Instead, the authors showed that CD147 mediates the degradation of $\mathrm{A} \beta$ possibly via stimulating the production of the metalloproteases (MMPs). The discrepancies between these two studies could be due to methodological differences, and it is possible that CD147 may have varying functions in different cell lines. Vetrivel and colleagues used HEK-293 (compared to CHO cells used the Zhou et al study) overexpressing CD147, which is known to contain an abundance of proteases that degrade $A \beta$. Although CD147, along with TMP21, co-purified in a high molecular complex with endogenous $\gamma$-secretase, these proteins could not be affinity captured with $\gamma$-secretase inhibitors, indicating that they are not part of the active $\gamma$-secretase complex ${ }^{90}$. These findings support that both CD147 and TMP21 may act to control A $\beta$ levels within the cell but they most likely are not part of the core components of the $\gamma$-secretase complex, affecting A $\beta$ levels indirectly.

\section{Presenilin Mutations}

In the early 90's genetic linkage studies, mapped a new AD gene to the AD3 locus on chromosome 14q24.3 ${ }^{91,92}$. Sherrington and colleagues in $1995{ }^{93}$ located the presenilin 1 
PSEN1 gene in two clusters of the AD3 locus. A second gene was mapped to the AD4 locus on chromosome 1q31.42, termed presenilin 2 (PSEN2) in which mutations were first identified in a Volga German kindred containing seven related families, clinically diagnosed with autosomal dominant EOAD ${ }^{94,95}$. The protein products PS1 and PS2 share almost 67\% sequence similarity but may have distinct functions (see below). Mutations in PS1 and PS2 account for the majority of early onset familial Alzheimer's disease cases. To date 176 mutations in PS1 and 14 mutations in PS2 have been reported in 390 and 23 families, respectively (for list of mutations refer to http://www.molgen.ua.ac.be/ADMutations/). Cases with PS2 mutations typically have later ages of onset of AD with the majority associated with an average age of onset considered to be late onset $\mathrm{AD}$ (70-73yrs) ${ }^{94-97}$. In contrast, mutations in PS1 are associated with earlier ages of onset ranging from 24-59 yrs old. Although the mutations are spread throughout the presenilin molecules, they appear to be concentrated around or within the transmembrane regions of the molecule, suggesting that these regions may be critical for protein function. Indeed, the conserved aspartate residues (D257 and D385) in transmembrane domain (TMD) 6 and 7 are critical for $\gamma$-secretase activity and may constitute the catalytic core of the complex ${ }^{21,54}$. Other residues such as R389, the C-terminal PAL motif and Cys residues in transmembrane domains 1 and 8 also appear to have important roles in catalytic activities, and in the formation of the postulated ring-like structure for the presenilins [reviewed in ${ }^{81}$ ].

For many years it was thought that presenilin mutations led to an increase in the more pathogenic $A \beta 42$ or an increase in the $A \beta 42 / 40$ ratio in vitro and in vivo ${ }^{50-52,98-102}$. However, this notion is changing with a loss of function explaining an increase in $A \beta 42$ production 103,104. Some evidence for presenilin mutations causing a loss of function has come from studies that have showed that presenilin mutations result in the loss of Notch signaling ${ }^{105}$. Recent experiments have lead us to re-evaluate the effects of clinical presenilin mutations on APP proteolytic processing in cells deficient of wild-type PS1 or in stably transfected cell lines ${ }^{106,107}$. These studies have measured the absolute levels of $A \beta 40$ and $A \beta 42$ generated from these cells and confirmed that the majority of the PS1/PS2 mutations resulted in an increase in $A \beta 42 / A \beta 40$ ratio. However, these studies also showed that some mutations led to a reduction in the levels of $A \beta 40$, together with the two additional fragments generated from $\gamma$-secretase enzyme activity [Notch and APP intracellular domains, (NICD and AICD, 
respectively)] and the accumulation of APP-C99 fragments, similar to that observed in cells lacking presenilins 106,107. These studies suggest that these mutations maybe altering the "normal" function of presenilins to generate A $\beta 40$, NICD or AICD, favoring the production of $\mathrm{A} \beta 42$.

\section{TARGETING $\gamma$-SECRETASE AS A POTENTIAL THERAPEUTIC FOR ALZHEIMER'S DISEASE.}

Currently, acetyl cholinesterase inhibitors (donepezil, rivastigmine and galantamine) and the N-methyl-D-aspartate receptor antagonist, memantine are the only available treatments for AD. Acetylcholine esterase inhibitors (AChI) prevent the breakdown of the neurotransmitter, acetylcholine, thereby conserving this neurotransmitter at synaptic junctions and compensating for loss of cholinergic circuits ${ }^{108}$. However, in clinical trials (and in practice) the cognitive benefits of these inhibitors are minimal in which more than half the subjects show no measurable improvement. The window of efficacy in those patients in which AChI's show benefit averages 6-12 months and then rapidly reduce as brain deterioration worsens (reviewed in ${ }^{109}$ ). Another prevalent neurotransmitter is glutamate, which when released presynaptically is essential in learning and memory via facilitation of the n-methyl-d- aspartate (NMDA) receptors allowing small influxes of calcium into stimulated nerve cells. This inturn triggers changes required for long term potentiation, culminating in formation of memory trace ${ }^{110}$. Excess glutamate can overstimulate NMDA receptors, allowing too much calcium into nerve cells, resulting in functional disruption and cell death. Memantine is an NMDA-receptor antagonist that although shows no benefit in mild-to-moderate AD, it is FDA approved for the treatment of moderate-severe $\mathrm{AD}{ }^{111}$. Limited, but statistically significant benefits for improved cognition, behaviour, and activities of daily living in AD patients over a six-month trial period has been observed for Memantine ${ }^{112}$.

The drugs mentioned above however only treat disease symptoms without targeting the underlying pathology or neurodegeneration. The majority of therapeutic strategies currently being developed and validated target the accumulation of $A \beta$ or its associated neuro-toxicity. One approach being pursued is modulating $A \beta$ production through the use of $\gamma$-secretase inhibitors (GSI's) or modulators (GSMs). However, the innate ability of the $\gamma$-secretase 
complex to cleave other substrates, has raised concerns about the specificity, selectivity and toxicity of agents aimed at inhibiting or modulating $\gamma$-secretase activity.

\section{$\gamma$-Secretase: The Multi-Substrate Enzyme}

Currently it is thought that the $\gamma$-secretase enzyme cleaves more than 50 different transmembrane proteins ${ }^{113-115}$, this has dubbed the enzyme with the name "the proteasome of the membrane". The list of substrates for $\gamma$-secretase include epithelial (E)- and neural (N)cadherins that are thought to play a major role in cell adhesion ${ }^{116}$, CD44 (role) ${ }^{117}$ and ErbB4 which plays a significant role in neuronal development by regulating cell proliferation and differentiation ${ }^{118}$. The intracellular domain released from the cleavage of Erb-B4 has been shown to mediate apoptosis. A more comprehensive list of substrates are shown in table 1.

Apart from APP, the second most studied substrate for the $\gamma$-secretase, and possibly the most pharmacologically relevant, is the Notch receptor ${ }^{119-121}$. Notch receptors play a vital role in cell signalling events and not only during embryogenesis but also in the adulthood 122,123. The signalling pathway is activated with one of five DSL (Delta and Serrate) ligands. During maturation, the Notch receptor is first cleaved by a furin like protease, at the S1 site of the extracellular domain resulting in two fragments, the Notch extracellular domain (NECD) and the transmembrane domain (NTM) which are held together by a heterodimerisation domain (HD) ${ }^{124}$. Upon interaction with its ligand, the metalloprotease, ADAM cleaves at the S2 site of extracellular domain of the Notch receptor (Figure 3). Two ADAMs have been implicated in the cleavage of Notch at the S2 site, ADAM10 and ADAM17. Interestingly, these enzymes also perform $\alpha$-secretase cleavage of APP, providing additional evidence that Notch undergoes similar proteolytic processing to APP. ADAM10 itself has also recently been shown to undergo $\gamma$-secretase cleavage to liberate an ICD which translocates to the nucleus and thought to be involved in gene regulation ${ }^{125}$. This may also be a process by which ADAM10 activity is regulated.

Following cleavage at the S2 site, the NTM then undergoes proteolysis at the S3/S4 sites by $\gamma$-secretase, liberating the Notch intracellular domain (NICD) which then translocates to the nucleus and activates target gene expression ${ }^{10,126,127}$. The intramembrane cleavage of Notch is referred to as the dual-intramembrane proteolysis since there are two $\gamma$-secretase cleavage sites (S3 and S4). The S3 cleavage site occurs at the interface between the cytosol 
and membrane liberating the NICD ${ }^{10,126}$. The S4 cleavage site near the middle of the transmembrane domain has been shown to liberate a fragment referred to as $\mathrm{N} \beta^{128,129}$. The Cterminus of $\mathrm{N} \beta$ has a similar sequence to that of $\mathrm{A} \beta$. Further, as with $\mathrm{A} \beta 42$ levels, presenilin mutations have been associated with an increase in $N \beta 25$, the longer version of $N \beta{ }^{128}$. The function of this fragment within the cell still remains unknown.

Notch and APP have been shown to compete for $\gamma$-secretase activity. Using an in vitro $\gamma$-secretase activity assay that cleaves Notch and APP-based substrates, Kimberly et al., ${ }^{130}$ showed that these substrates prevented each other's cleavage, suggesting that the same $\gamma$ secretase complex is responsible for the processing of both substrates. Berezovska et al., ${ }^{131}$ showed that treatment of neurons with the Notch ligand delta led to a dose dependent reduction in A $\beta$ levels and over-expression of APP led to a reduction in Notch signalling. Further, over-expressing either of the two direct substrates for $\gamma$-secretase, C99 and the N $\Delta \mathrm{EC}$ (truncated version of NECD that requires a PS1-dependent cleavage event), led to a reduction in generated products (NICD and $A \beta$, respectively) ${ }^{132}$. Further, transfection with NICD also down-regulated $A \beta$ production and was associated with a reduction in PS1 transcription and protein levels. These results suggest that competition may exist for the $\gamma$-secretase catalytic site between different substrates where generation of a product from one substrate may regulate the proteolytic processing of other $\gamma$-secretase substrates. Further, the work of Lleo et al. ${ }^{132}$ suggests that Notch signalling may exert some control on PS1 expression which may ultimately impact on APP processing to generate A $\beta$. Although these studies suggest that the same enzyme complex performs the majority of the processing of the substrates, there is also strong evidence that multiple enzyme complexes with varied functions may also exist.

The existence of two presenilin molecules (PS1 and PS2) as possible catalytic components of the $\gamma$-secretase enzyme would suggest that multiple complexes could possibly occur. Although PS1 and PS2 share an overall protein sequence similarity of 67\%, several lines of evidence suggest that these proteins may have quite distinct biological functions. Mice lacking PS1 die before birth and the embryos display severe skeletal and brain deformities, whilst mice lacking PS2 develop a mild pulmonary fibrosis and haemorrhages with age ${ }^{55,133-135}$. Neuronal cultures isolated from PS1 ablated mice when compared to those isolated from PS2 knockout mice exhibit lower A $\beta$ production ${ }^{134,136}$. Lai and colleagues also provided evidence suggesting the existence of distinct PS1 containing and PS2 containing 
complexes ${ }^{136}$. In vivo, PS2 and PS1 transgenic mice have differential effects on $\gamma$-secretase activity ${ }^{137}$. There is evidence to suggest that two $A \beta$ generating complexes may exist, whereby PS1 containing complexes produce both $\mathrm{A} \beta 40$ and $\mathrm{A} \beta 42$, and PS2 containing complexes are involved in $\mathrm{A} \beta 42$ (but not $\mathrm{A} \beta 40$ ) production. Recently, Placanica and colleagues $2009{ }^{138}$ provided further evidence for distinct PS1 and PS2 $\gamma$-secretase complexes in the generation of $A \beta$. The authors described that the two complexes are in dynamic equilibrium, possibly under control of Pen-2 expression.

As there are 2 presenilin genes (PS1 and PS2) and 3 Aph-1 genes (Aph-1aS, Aph-1aL, and $A p h-1 b)$, at least 6 different $\gamma$-secretase complexes can theoretically occur within a cell. Evidence suggests that the aph1a containing complexes are crucial for Notch signalling during embryogenesis ${ }^{139,140}$. Aph-1a knockout mice are embryonic lethal compared to Aph$1 b$ knockout mice, which appear to be phenotypically normal, and the absence of Aph-1a disrupts the formation of an active $\gamma$-secretase complex. ${ }^{140}$. Collectively, these data suggests that complexes containing aph-1a are active and those containing aph-1b are possibly redundant. However, aph-1b complexes have recently been shown to have a role in a neurregulin-1 (Nrg-1) signalling. Aph-1b knockout mice show signs of schizophrenia including hypersensitivity to psychiatric drugs, sensorimotor gating abnormalities and working memory deficits ${ }^{141}$. This finding is to be expected given the enrichment of aph-1b in the mouse pre-frontal cortex ${ }^{141}$. In summary, there is sufficient evidence to suggest the presence of multiple $\gamma$-secretase complexes with different functional activities and substrates. These characteristics are an important consideration when developing appropriate agents aimed at inhibiting $\mathrm{A} \beta$ production.

\section{Inhibiting Or Modulating $\gamma$-Secretase Activity}

A number of compounds that inhibit or modulate $\gamma$-secretase activity have been identified. These include transition state analogues (e.g: L-685,458, WPE-II-31C), dipeptidic inhibitors (DAPT, LY450139), sulphonamide (BMS-299897), kinase inhibitor (imatinib) and NSAIDs (R-Flurbiprofen). Transition state analogues are compounds with a chemical structure, resembling the transition state of a substrate molecule in an enzymatic reaction. Of these, L-685,458 has been extensively studied. This inhibitor was originally shown to inhibit 
$\gamma$-secretase activity on APP to reduce A $\beta$ generation ${ }^{142,143}$ providing some initial evidence that this agent could be a suitable amyloid lowering drug. However, any promise that this agent may be a disease modifying drug was soon dispelled as it was also shown to inihbit the cleavage and subsequent signalling of a number of other substrates including, Notch ${ }^{144,145}$, ErbB-4 ${ }^{121,146}$ and gamma-protocadherins ${ }^{147}$, resulting in the detrimental effects on a number of cellular processes such as cell development, proliferation and adhesion. The ability of this inhibitor to bind PS1 ${ }^{142,148}$ provided evidence that it may be used as a detection agent for $\gamma$ secretase. Indeed radiolabelled [H3] L-685, 458 was shown as an excellent tracer for $\gamma$ secretase activity in vivo ${ }^{149}$. This agent could also show some promise for treatment of cancers. The inhibitors effects on Notch processing has revealed that this inhibitor exerts antitumour activity ${ }^{150}$. The chronic treatment of lymphoblastic leukemia cell lines with L-685, 458 has been shown to reversibly inhibited cell proliferation and caused cell block in sensitive T-cell acute lymphoblastic leukemia cell lines ${ }^{151}$. Despite showing some promise as a tumour suppressor, the in-vitro effects of this inhibitor on APP and other substrates indicate that that this would not be a suitable treatment for AD.

Amongst the first dipetide inhibitor reported to be an active agent in-vivo, where it inhibited $A \beta$ production in the plasma and brain in an APP transgenic mouse model was DAPT ${ }^{152,153}$. Modifications to DAPT led to the development of more potent inhibitors including compound $\mathrm{E}^{57}$ and related analogues that have shown better efficacy in vivo, including LY-411,575 ${ }^{154}$ and LY-450,139 ${ }^{155,156}$. Although Ly-411,575 chronically reduced $A \beta$ levels in plasma and brain, elevated doses resulted in severe gastrointestinal toxicity and interfered with maturation of B- and T-lymphocytes ${ }^{157,158}$, presumably due to its effects at inhibiting cleavage of other substrates such as Notch. Clinical studies have been reported for only one $\gamma$-secretase inhibitor, LY-4150,139 ${ }^{155,156}$. These reports showed that the inhibitor reduced plasma $A \beta$ levels but had no effect on CSF $A \beta$, reflecting the low doses being used. Although increasing the dose of this inhibitor may show more beneficial results in the CNS, caution must be taken considering the toxic side effects of its analogues.

A recent clinical trial with the NSAID, R-flurbiprofen (also called Tarenflurbil and Flurizan $^{\mathrm{TM}}$ ) as a treatment for $\mathrm{AD}$ failed at phase 3, despite showing promising results in phase $2{ }^{159}$. In phase 2 clinical trials ${ }^{160}$ compared to placebo treated patients with mild-AD, those administered R- flurbiprofen showed improvements on ADCS-ADL scale (an outcome 
measure of drug efficacy that is commonly used in AD clinical trials). However, in a large phase III clinical trial in mild $\mathrm{AD}$ patients, those receiving R-flurbiprofen significantly deteriorated more than the placebo treated patients on the Clinical dementia rating scores ${ }^{159}$. A simple explanation of the failure of R-flurbiprofen could be that $\gamma$-secretase enzyme is not a suitable target. If this is the case than perhaps the same can be said for other drug agents that target the $A \beta$ molecule and therefore questioning the validity of the amyloid hypothesis. However, the failure of the trial could simply be due to the weak pharmacological activity in the CNS and the poor pharmokinetic profile (as shown by the high doses (-800 $\mathrm{mg}$ ) of this drug that were required to show benefits in phase II trials. In addition, anti-cytochrome oxidase (COX) activity at these high doses, was most likely an explanation for severe gastrointestinal side effects (peptic ulcers) in several of those patients treated with R-flurbiprofen (8 compared to only 1 in placebo group) ${ }^{159}$. The inhibitory effects of NSAIDs on microglia may also contribute to the failure of this agent. Microglial, surround plaques and activate phagocytosis and subsequent clearance of $A \beta$ and also stimulate compensatory neurogenesis in the hippocampus ${ }^{161}$. Inhibiting microglia activation could thereby compromise clearance of $\mathrm{A} \beta$ and neuronal homeostasis.

Despite the apparent failure of gamma secretase inhibitors and modulators, the enzyme is still pursued as target for developing appropriate therapies. Assessing the efficacy of a number of kinase inhibitors at reducing $A \beta$ production without altering Notch cleavage showed that the Ab1 kinase inhibitor imatinib (GleevecTM) exhibited the desired effects ${ }^{162}$. Similar results were shown with an inhibitor of Janus kinase 3 (Jak3) inhibitor ${ }^{163}$. Screening of large drug libraries for those agents that reduce $A \beta$ with no effect on Notch processing are also currently being pursued ${ }^{164}$. Although, APP and Notch appear to be currently the most physiological and pharmacological substrates, the other substrates also play important roles in maintaining cell homeostasis and are also important to consider when developing therapies aimed at selectively targeting $A \beta$.

\section{CONCLUSION}

There is no doubt that the complexity of this unique enzyme makes it a very difficult target for developing appropriate and effective treatments for AD. Its ability to proteolytically cleave a plethora of membrane bound substrates highlights the importance of this enzyme in normal cell function. Although, intensive research in the past 10 years has revealed a wealth 
of information, the exact structure and function of each of its components and where within the enzyme to target and how it is active within a hydrophobic environment with the cell membrane still remain unclear. More detailed insight into the molecular workings of this enzyme is still required not only to develop more effective drug agents, but identify cellular pathways in which gamma secretase is such a critical component.

\section{ACKNOWLEDGEMENTS}

SK is supported by the Centre of Excellence for Alzheimer's Disease Research and Care. Professor Martins is supported by grants from the McCusker Foundation for Alzheimer's Disease Research, Department of Veterans Affairs, National Health and Medical Research Council (NHMRC) and Hollywood Private Hospital (RNM). G.V. is generously supported by a grant from Mr Warren Milner (Milner English College-Perth, Western Australia) and Ms Helen Sewell. 


\section{REFERENCES:}

1. Verdile G, Fuller S, Atwood CS, Laws SM, Gandy SE, Martins RN. The role of beta amyloid in Alzheimer's disease: still a cause of everything or the only one who got caught? Pharmacological Research 2004; 50: 397-409.

2. Reddy PH. Amyloid precursor protein-mediated free radicals and oxidative damage: implications for the development and progression of Alzheimer's disease. J Neurochem 2006; 96: 1-13.

3. Verdile G, Groth D, Mathews PM, St George-Hyslop P, Fraser PE, Ramabhadran TV, Kwok JB, Schofield PR, Carter T, Gandy S, Martins RN. Baculoviruses expressing the human familial Alzheimer's disease presenilin 1 mutation lacking exon 9 increase levels of an amyloid beta-like protein in Sf9 cells. Mol Psychiatry 2004; 9: 594-602.

4. Gandy S, Naslund J, Nordstedt C. Alzheimer's disease. Molecular consequences of presenilin1 mutation. Nature 2001; 411: 654-6.

5. Gu Y, Misonou H, Sato T, Dohmae N, Takio K, Ihara Y. Distinct intramembrane cleavage of the beta-amyloid precursor protein family resembling gamma-secretase-like cleavage of Notch. J Biol Chem 2001; 276: 35235-8.

6. Sastre M, Steiner H, Fuchs K, Capell A, Multhaup G, Condron MM, Teplow DB, Haass C. Presenilin-dependent gamma-secretase processing of beta-amyloid precursor protein at a site corresponding to the S3 cleavage of Notch. EMBO Rep 2001; 2: 835-41.

7. Yu C, Kim SH, Ikeuchi T, Xu H, Gasparini L, Wang R, Sisodia SS. Characterization of a presenilin-mediated amyloid precursor protein carboxyl-terminal fragment gamma. Evidence for distinct mechanisms involved in gamma -secretase processing of the APP and Notch1 transmembrane domains. J Biol Chem 2001; 276: 43756-60.

8. Weidemann A, Eggert S, Reinhard FB, Vogel M, Paliga K, Baier G, Masters CL, Beyreuther K, Evin G. A novel epsilon-cleavage within the transmembrane domain of the Alzheimer amyloid precursor protein demonstrates homology with Notch processing. Biochemistry 2002; 41: 2825-35.

9. Raychaudhuri M, Mukhopadhyay D. AICD and its adaptors - in search of new players. $J$ Alzheimers Dis 2007; 11: 343-58.

10. Schroeter EH, Kisslinger JA, Kopan R. Notch-1 signalling requires ligand-induced proteolytic release of intracellular domain. Nature 1998; 393: 382-6.

11. Zhao G, Mao G, Tan J, Dong Y, Cui MZ, Kim SH, Xu X. Identification of a new presenilindependent zeta-cleavage site within the transmembrane domain of amyloid precursor protein. J Biol Chem 2004; 279: 50647-50.

12. Qi-Takahara Y, Morishima-Kawashima M, Tanimura Y, Dolios G, Hirotani N, Horikoshi Y, Kametani F, Maeda M, Saido TC, Wang R, Ihara Y. Longer forms of amyloid beta protein: implications for the mechanism of intramembrane cleavage by gamma-secretase. $J$ Neurosci 2005; 25: 436-45.

13. Zhao G, Tan J, Mao G, Cui MZ, Xu X, Dong Y, Singh N, Sun L, Kim SH. The same gammasecretase accounts for the multiple intramembrane cleavages of APP. J Neurochem 2007; 100: 1234-46.

14. Parks AL, Curtis D. Presenilin diversifies its portfolio. Trends Genet 2007; 23: 140-50.

15. Kimberly WT, LaVoie MJ, Ostaszewski BL, Ye W, Wolfe MS, Selkoe DJ. Gamma-secretase is a membrane protein complex comprised of presenilin, nicastrin, Aph-1, and Pen-2. Proc Natl Acad Sci U S A 2003; 100: 6382-7.

16. Yu G, Chen F, Levesque G, Nishimura M, Zhang DM, Levesque L, Rogaeva E, Xu D, Liang Y, Duthie M, St George-Hyslop PH, Fraser PE. The presenilin 1 protein is a component of a high molecular weight intracellular complex that contains beta-catenin. J Biol Chem 1998; 273: 16470-5. 
17. Farmery MR, Tjernberg LO, Pursglove SE, Bergman A, Winblad B, Naslund J. Partial purification and characterization of gamma-secretase from post-mortem human brain. $J$ Biol Chem 2003; 278: 24277-84.

18. Edbauer D, Winkler E, Haass C, Steiner H. Presenilin and nicastrin regulate each other and determine amyloid beta-peptide production via complex formation. Proc Natl Acad Sci U S A 2002; 99: 8666-71.

19. Steiner H, Winkler E, Edbauer D, Prokop S, Basset G, Yamasaki A, Kostka M, Haass C. PEN-2 is an integral component of the gamma-secretase complex required for coordinated expression of presenilin and nicastrin. $J$ Biol Chem 2002; 277: 39062-5.

20. Li T, Ma G, Cai H, Price DL, Wong PC. Nicastrin is required for assembly of presenilin/gamma-secretase complexes to mediate Notch signaling and for processing and trafficking of beta-amyloid precursor protein in mammals. J Neurosci 2003; 23: 3272-7.

21. Nyabi O, Bentahir M, Horre K, Herreman A, Gottardi-Littell N, Van Broeckhoven C, Merchiers P, Spittaels K, Annaert W, De Strooper B. Presenilins mutated at Asp-257 or Asp385 restore Pen-2 expression and Nicastrin glycosylation but remain catalytically inactive in the absence of wild type Presenilin. J Biol Chem 2003; 278: 43430-6.

22. Li YM, Lai MT, Xu M, Huang Q, DiMuzio-Mower J, Sardana MK, Shi XP, Yin KC, Shafer JA, Gardell SJ. Presenilin 1 is linked with gamma-secretase activity in the detergent solubilized state. Proc Natl Acad Sci U S A 2000; 97: 6138-43.

23. Francis R, McGrath G, Zhang J, Ruddy DA, Sym M, Apfeld J, Nicoll M, Maxwell M, Hai B, Ellis MC, Parks AL, Xu W, Li J, Gurney M, Myers RL, Himes CS, Hiebsch R, Ruble C, Nye JS, Curtis D. aph-1 and pen-2 are required for Notch pathway signaling, gamma-secretase cleavage of betaAPP, and presenilin protein accumulation. Dev Cell 2002; 3: 85-97.

24. Lee SF, Shah S, Li H, Yu C, Han W, Yu G. Mammalian APH-1 interacts with presenilin and nicastrin and is required for intramembrane proteolysis of amyloid-beta precursor protein and Notch. J Biol Chem 2002; 277: 45013-9.

25. Gu Y, Chen F, Sanjo N, Kawarai T, Hasegawa H, Duthie M, Li W, Ruan X, Luthra A, Mount HT, Tandon A, Fraser PE, St George-Hyslop P. APH-1 interacts with mature and immature forms of presenilins and nicastrin and may play a role in maturation of presenilin.nicastrin complexes. J Biol Chem 2003; 278: 7374-80.

26. Hu Y, Fortini ME. Different cofactor activities in gamma-secretase assembly: evidence for a nicastrin-Aph-1 subcomplex. J Cell Biol 2003; 161: 685-90.

27. Luo WJ, Wang H, Li H, Kim BS, Shah S, Lee HJ, Thinakaran G, Kim TW, Yu G, Xu H. PEN-2 and APH-1 coordinately regulate proteolytic processing of presenilin 1. J Biol Chem 2003; 278: 7850-4.

28. Takasugi N, Tomita T, Hayashi I, Tsuruoka M, Niimura M, Takahashi Y, Thinakaran G, Iwatsubo T. The role of presenilin cofactors in the gamma-secretase complex. Nature 2003; 422: 438-41.

29. Edbauer D, Winkler E, Regula JT, Pesold B, Steiner H, Haass C. Reconstitution of gammasecretase activity. Nat Cell Biol 2003; 5: 486-8.

30. Hayashi I, Urano Y, Fukuda R, Isoo N, Kodama T, Hamakubo T, Tomita T, Iwatsubo T. Selective reconstitution and recovery of functional gamma-secretase complex on budded baculovirus particles. J Biol Chem 2004; 279: 38040-6.

31. Zhang L, Lee J, Song L, Sun X, Shen J, Terracina G, Parker EM. Characterization of the reconstituted gamma-secretase complex from Sf9 cells co-expressing presenilin 1, nicastrin [correction of nacastrin], aph-1a, and pen-2. Biochemistry 2005; 44: 4450-7.

32. Brunkan AL, Martinez M, Wang J, Walker ES, Beher D, Shearman MS, Goate AM. Two domains within the first putative transmembrane domain of presenilin 1 differentially influence presenilinase and gamma-secretase activity. J Neurochem 2005; 94: 1315-28.

33. Lazarov VK. Electron microscopic structure of purified, active gammasecretase reveals an aqueous intramembrane chamber and two pores. 2006.

34. Ogura T, Mio K, Hayashi I, Miyashita H, Fukuda R, Kopan R, Kodama T, Hamakubo T, Iwastubo T, Tomita T, Sato C. Three-dimensional structure of the [gamma]-secretase complex. Biochemical and Biophysical Research Communications 2006; 343: 525-534. 
35. Wang Y, Zhang Y, Ha Y. Crystal structure of a rhomboid family intramembrane protease. Nature 2006; 444: 179-80.

36. Kim AC, Oliver DC, Paetzel M. Crystal structure of a bacterial signal Peptide peptidase. $J$ Mol Biol 2008; 376: 352-66.

37. Stahlberg H, Fotiadis D, Scheuring S, Remigy H, Braun T, Mitsuoka K, Fujiyoshi Y, Engel A. Two-dimensional crystals: a powerful approach to assess structure, function and dynamics of membrane proteins. FEBS Lett 2001; 504: 166-72.

38. Capell A, Beher D, Prokop S, Steiner H, Kaether C, Shearman MS, Haass C. Gammasecretase complex assembly within the early secretory pathway. J Biol Chem 2005; 280: 6471-8.

39. Kim SH, Yin YI, Li YM, Sisodia SS. Evidence that assembly of an active gamma-secretase complex occurs in the early compartments of the secretory pathway. J Biol Chem 2004; 279: 48615-9.

40. LaVoie MJ, Fraering PC, Ostaszewski BL, Ye W, Kimberly WT, Wolfe MS, Selkoe DJ. Assembly of the gamma-secretase complex involves early formation of an intermediate subcomplex of Aph-1 and nicastrin. J Biol Chem 2003; 278: 37213-22.

41. Fortna RR, Crystal AS, Morais VA, Pijak DS, Lee VM, Doms RW. Membrane topology and nicastrin-enhanced endoproteolysis of APH-1, a component of the gamma-secretase complex. J Biol Chem 2004; 279: 3685-93.

42. Lee SF, Shah S, Yu C, Wigley WC, Li H, Lim M, Pedersen K, Han W, Thomas P, Lundkvist J, Hao YH, Yu G. A conserved GXXXG motif in APH-1 is critical for assembly and activity of the gamma-secretase complex. J Biol Chem 2004; 279: 4144-52.

43. Niimura M, Isoo N, Takasugi N, Tsuruoka M, Ui-Tei K, Saigo K, Morohashi Y, Tomita T, Iwatsubo T. Aph-1 contributes to the stabilization and trafficking of the gamma-secretase complex through mechanisms involving intermolecular and intramolecular interactions. $J$ Biol Chem 2005; 280: 12967-75.

44. Shirotani K, Edbauer D, Kostka M, Steiner H, Haass C. Immature nicastrin stabilizes APH-1 independent of PEN-2 and presenilin: identification of nicastrin mutants that selectively interact with APH-1. J Neurochem 2004; 89: 1520-7.

45. Zhang YW, Luo WJ, Wang H, Lin P, Vetrivel KS, Liao F, Li F, Wong PC, Farquhar MG, Thinakaran G, Xu H. Nicastrin is critical for stability and trafficking but not association of other presenilin/gamma-secretase components. J Biol Chem 2005; 280: 17020-6.

46. Shah S, Lee S-F, Tabuchi K, Hao Y-H, Yu C, LaPlant Q, Ball H, Dann Iii CE, Südhof T, Yu G. Nicastrin Functions as a [gamma]-Secretase-Substrate Receptor. Cell 2005; 122: 435-447.

47. Hasegawa H, Sanjo N, Chen F, Gu YJ, Shier C, Petit A, Kawarai T, Katayama T, Schmidt SD, Mathews PM, Schmitt-Ulms G, Fraser PE, St George-Hyslop P. Both the sequence and length of the $\mathrm{C}$ terminus of PEN-2 are critical for intermolecular interactions and function of presenilin complexes. J Biol Chem 2004; 279: 46455-63.

48. Watanabe N, Tomita T, Sato C, Kitamura T, Morohashi Y, Iwatsubo T. Pen-2 is incorporated into the gamma-secretase complex through binding to transmembrane domain 4 of presenilin 1. J Biol Chem 2005; 280: 41967-75.

49. Kim SH, Sisodia SS. Evidence that the "NF" motif in transmembrane domain 4 of presenilin 1 is critical for binding with PEN-2. J Biol Chem 2005; 280: 41953-66.

50. Borchelt DR, Thinakaran G, Eckman CB, Lee MK, Davenport F, Ratovitsky T, Prada CM, Kim G, Seekins S, Yager D, Slunt HH, Wang R, Seeger M, Levey AI, Gandy SE, Copeland NG, Jenkins NA, Price DL, Younkin SG, Sisodia SS. Familial Alzheimer's disease-linked presenilin 1 variants elevate Abeta1-42/1-40 ratio in vitro and in vivo. Neuron 1996; 17: 1005-13.

51. Lemere CA, Lopera F, Kosik KS, Lendon CL, Ossa J, Saido TC, Yamaguchi H, Ruiz A, Martinez A, Madrigal L, Hincapie L, Arango JC, Anthony DC, Koo EH, Goate AM, Selkoe DJ. The E280A presenilin 1 Alzheimer mutation produces increased A beta 42 deposition and severe cerebellar pathology. Nat Med 1996; 2: 1146-50.

52. Xia W, Zhang J, Kholodenko D, Citron M, Podlisny MB, Teplow DB, Haass C, Seubert P, Koo EH, Selkoe DJ. Enhanced production and oligomerization of the 42-residue amyloid 
beta-protein by Chinese hamster ovary cells stably expressing mutant presenilins. J Biol Chem 1997; 272: 7977-82.

53. De Strooper B, Saftig P, Craessaerts K, Vanderstichele H, Guhde G, Annaert W, Von Figura K, Van Leuven F. Deficiency of presenilin-1 inhibits the normal cleavage of amyloid precursor protein. Nature 1998; 391: 387-90.

54. Wolfe MS, Xia W, Ostaszewski BL, Diehl TS, Kimberly WT, Selkoe DJ. Two transmembrane aspartates in presenilin-1 required for presenilin endoproteolysis and gammasecretase activity. Nature 1999; 398: 513-7.

55. Steiner H, Duff K, Capell A, Romig H, Grim MG, Lincoln S, Hardy J, Yu X, Picciano M, Fechteler K, Citron M, Kopan R, Pesold B, Keck S, Baader M, Tomita T, Iwatsubo T, Baumeister R, Haass C. A loss of function mutation of presenilin-2 interferes with amyloid beta-peptide production and Notch signaling. J Biol Chem 1999; 274: 28669-73.

56. Esler WP, Kimberly WT, Ostaszewski BL, Diehl TS, Moore CL, Tsai JY, Rahmati T, Xia W, Selkoe DJ, Wolfe MS. Transition-state analogue inhibitors of gamma-secretase bind directly to presenilin-1. Nat Cell Biol 2000; 2: 428-34.

57. Seiffert D, Mitchell T, Stern AM, Roach A, Zhan Y, Grzanna R. Positive-negative epitopetagging of beta amyloid precursor protein to identify inhibitors of A beta processing. Brain Res Mol Brain Res 2000; 84: 115-26.

58. Verdile G, Gandy SE, Martins RN. The role of presenilin and its interacting proteins in the biogenesis of Alzheimer's beta amyloid. Neurochem Res 2007; 32: 609-23.

59. Thinakaran G, Teplow DB, Siman R, Greenberg B, Sisodia SS. Metabolism of the "Swedish" amyloid precursor protein variant in neuro2a (N2a) cells. Evidence that cleavage at the "betasecretase" site occurs in the golgi apparatus. J Biol Chem 1996; 271: 9390-7.

60. Podlisny MB, Citron M, Amarante P, Sherrington R, Xia W, Zhang J, Diehl T, Levesque G, Fraser P, Haass C, Koo EH, Seubert P, St George-Hyslop P, Teplow DB, Selkoe DJ. Presenilin proteins undergo heterogeneous endoproteolysis between Thr291 and Ala299 and occur as stable $\mathrm{N}$ - and C-terminal fragments in normal and Alzheimer brain tissue. Neurobiol Dis 1997; 3: 325-37.

61. Levitan D, Lee J, Song L, Manning R, Wong G, Parker E, Zhang L. PS1 N- and C-terminal fragments form a complex that functions in APP processing and Notch signaling. Proc Natl Acad Sci U S A 2001; 98: 12186-90.

62. Laudon H, Mathews PM, Karlstrom H, Bergman A, Farmery MR, Nixon RA, Winblad B, Gandy SE, Lendahl U, Lundkvist J, Naslund J. Co-expressed presenilin 1 NTF and CTF form functional gamma-secretase complexes in cells devoid of full-length protein. $J$ Neurochem 2004; 89: 44-53.

63. Capell A, Grunberg J, Pesold B, Diehlmann A, Citron M, Nixon R, Beyreuther K, Selkoe DJ, Haass C. The proteolytic fragments of the Alzheimer's disease-associated presenilin- 1 form heterodimers and occur as a 100-150-kDa molecular mass complex. J Biol Chem 1998; 273 : 3205-11.

64. Seeger M, Nordstedt C, Petanceska S, Kovacs DM, Gouras GK, Hahne S, Fraser P, Levesque L, Czernik AJ, George-Hyslop PS, Sisodia SS, Thinakaran G, Tanzi RE, Greengard P, Gandy S. Evidence for phosphorylation and oligomeric assembly of presenilin 1. Proc Natl Acad Sci U S A 1997; 94: 5090-4.

65. Steiner H, Capell A, Pesold B, Citron M, Kloetzel PM, Selkoe DJ, Romig H, Mendla K, Haass C. Expression of Alzheimer's disease-associated presenilin-1 is controlled by proteolytic degradation and complex formation. J Biol Chem 1998; 273: 32322-31.

66. Beher D, Elle C, Underwood J, Davis JB, Ward R, Karran E, Masters CL, Beyreuther K, Multhaup G. Proteolytic fragments of Alzheimer's disease-associated presenilin 1 are present in synaptic organelles and growth cone membranes of rat brain. J Neurochem 1999; 72: 156473.

67. Yu G, Nishimura M, Arawaka S, Levitan D, Zhang L, Tandon A, Song YQ, Rogaeva E, Chen F, Kawarai T, Supala A, Levesque L, Yu H, Yang DS, Holmes E, Milman P, Liang Y, Zhang DM, Xu DH, Sato C, Rogaev E, Smith M, Janus C, Zhang Y, Aebersold R, Farrer LS, Sorbi 
S, Bruni A, Fraser P, St George-Hyslop P. Nicastrin modulates presenilin-mediated Notch/glp-1 signal transduction and betaAPP processing. Nature 2000; 407: 48-54.

68. Cervantes S, Gonzalez-Duarte R, Marfany G. Homodimerization of presenilin N-terminal fragments is affected by mutations linked to Alzheimer's disease. FEBS Lett 2001; 505: 81-6.

69. Schroeter EH, Ilagan MX, Brunkan AL, Hecimovic S, Li YM, Xu M, Lewis HD, Saxena MT, De Strooper B, Coonrod A, Tomita T, Iwatsubo T, Moore CL, Goate A, Wolfe MS, Shearman M, Kopan R. A presenilin dimer at the core of the gamma-secretase enzyme: insights from parallel analysis of Notch 1 and APP proteolysis. Proc Natl Acad Sci U S A 2003; 100: 13075-80.

70. Xia W, Wolfe MS. Intramembrane proteolysis by presenilin and presenilin-like proteases. $J$ Cell Sci 2003; 116: 2839-44.

71. Weihofen A, Binns K, Lemberg MK, Ashman K, Martoglio B. Identification of signal peptide peptidase, a presenilin-type aspartic protease. Science 2002; 296: 2215-8.

72. Nyborg AC, Kornilova AY, Jansen K, Ladd TB, Wolfe MS, Golde TE. Signal peptide peptidase forms a homodimer that is labeled by an active site-directed gamma-secretase inhibitor. J Biol Chem 2004; 279: 15153-60.

73. Friedmann E, Lemberg MK, Weihofen A, Dev KK, Dengler U, Rovelli G, Martoglio B. Consensus analysis of signal peptide peptidase and homologous human aspartic proteases reveals opposite topology of catalytic domains compared with presenilins. J Biol Chem 2004; 279: 50790-8.

74. Ponting CP, Hutton M, Nyborg A, Baker M, Jansen K, Golde TE. Identification of a novel family of presenilin homologues. Hum Mol Genet 2002; 11: 1037-44.

75. Sato T, Nyborg AC, Iwata N, Diehl TS, Saido TC, Golde TE, Wolfe MS. Signal peptide peptidase: biochemical properties and modulation by nonsteroidal antiinflammatory drugs. Biochemistry 2006; 45: 8649-56.

76. Lemberg MK, Martoglio B. Requirements for Signal Peptide Peptidase-Catalyzed Intramembrane Proteolysis. Molecular Cell 2002; 10: 735-744.

77. Wolfe MS, Kopan R. Intramembrane proteolysis: theme and variations. Science 2004; 305: 1119-23.

78. Fluhrer R, Fukumori A, Martin L, Grammer G, Haug-Kroper M, Klier B, Winkler E, Kremmer E, Condron MM, Teplow DB, Steiner H, Haass C. Intramembrane proteolysis of GXGD-type aspartyl proteases is slowed by a familial Alzheimer disease-like mutation. $J$ Biol Chem 2008; 283: 30121-8.

79. Leuchtenberger S, Beher D, Weggen S. Selective modulation of Abeta42 production in Alzheimer's disease: non-steroidal anti-inflammatory drugs and beyond. Curr Pharm Des 2006; 12: 4337-55.

80. Berezovska O, Ramdya P, Skoch J, Wolfe MS, Bacskai BJ, Hyman BT. Amyloid precursor protein associates with a nicastrin-dependent docking site on the presenilin 1-gammasecretase complex in cells demonstrated by fluorescence lifetime imaging. $J$ Neurosci 2003; 23: 4560-6.

81. Spasic D, Annaert W. Building gamma-secretase: the bits and pieces. J Cell Sci 2008; 121: 413-20.

82. Hansson EM, Stromberg K, Bergstedt S, Yu G, Naslund J, Lundkvist J, Lendahl U. Aph-1 interacts at the cell surface with proteins in the active gamma-secretase complex and membrane-tethered Notch. J Neurochem 2005; 92: 1010-20.

83. Urban S, Lee JR, Freeman M. Drosophila rhomboid-1 defines a family of putative intramembrane serine proteases. Cell 2001; 107: 173-82.

84. Prokop S, Haass C, Steiner H. Length and overall sequence of the PEN-2 C-terminal domain determines its function in the stabilization of presenilin fragments. J Neurochem 2005; 94: 5762.

85. Blum R, Feick P, Puype M, Vandekerckhove J, Klengel R, Nastainczyk W, Schulz I. Tmp21 and p24A, two type I proteins enriched in pancreatic microsomal membranes, are members of a protein family involved in vesicular trafficking. J Biol Chem 1996; 271: 17183-9. 
86. Barr FA, Preisinger C, Kopajtich R, Korner R. Golgi matrix proteins interact with p24 cargo receptors and aid their efficient retention in the Golgi apparatus. J Cell Biol 2001; 155: 88591.

87. Chen F, Hasegawa H, Schmitt-Ulms G, Kawarai T, Bohm C, Katayama T, Gu Y, Sanjo N, Glista M, Rogaeva E, Wakutani Y, Pardossi-Piquard R, Ruan X, Tandon A, Checler F, Marambaud P, Hansen K, Westaway D, St George-Hyslop P, Fraser P. TMP21 is a presenilin complex component that modulates gamma-secretase but not epsilon-secretase activity. Nature 2006; 440: 1208-12.

88. Zhou S, Zhou H, Walian PJ, Jap BK. CD147 is a regulatory subunit of the gamma-secretase complex in Alzheimer's disease amyloid beta-peptide production. Proc Natl Acad Sci U S A 2005; 102: 7499-504.

89. Vetrivel KS, Zhang X, Meckler X, Cheng H, Lee S, Gong P, Lopes KO, Chen Y, Iwata N, Yin KJ, Lee JM, Parent AT, Saido TC, Li YM, Sisodia SS, Thinakaran G. Evidence that CD147 modulation of beta-amyloid (Abeta) levels is mediated by extracellular degradation of secreted Abeta. J Biol Chem 2008; 283: 19489-98.

90. Winkler E, Hobson S, Fukumori A, Dumpelfeld B, Luebbers T, Baumann K, Haass C, Hopf C, Steiner H. Purification, pharmacological modulation, and biochemical characterization of interactors of endogenous human gamma-secretase. Biochemistry 2009; 48: 1183-97.

91. Schellenberg GD, Kamino K, Bryant EM, Moore D, Bird TD. Genetic heterogeneity, Down syndrome, and Alzheimer disease. Prog Clin Biol Res 1992; 379: 215-26.

92. St George-Hyslop P, Haines J, Rogaev E, Mortilla M, Vaula G, Pericak-Vance M, Foncin JF, Montesi M, Bruni A, Sorbi S, et al. Genetic evidence for a novel familial Alzheimer's disease locus on chromosome 14. Nat Genet 1992; 2: 330-4.

93. Sherrington R, Rogaev EI, Liang Y, Rogaeva EA, Levesque G, Ikeda M, Chi H, Lin C, Li G, Holman $\mathrm{K}$, et al. Cloning of a gene bearing missense mutations in early-onset familial Alzheimer's disease. Nature 1995; 375: 754-60.

94. Levy-Lahad E, Lahad A, Wijsman EM, Bird TD, Schellenberg GD. Apolipoprotein E genotypes and age of onset in early-onset familial Alzheimer's disease. Ann Neurol 1995; 38: 678-80.

95. Rogaev EI, Sherrington R, Rogaeva EA, Levesque G, Ikeda M, Liang Y, Chi H, Lin C, Holman K, Tsuda T, et al. Familial Alzheimer's disease in kindreds with missense mutations in a gene on chromosome 1 related to the Alzheimer's disease type 3 gene. Nature 1995; 376: 775-8.

96. Lao JI, Beyer K, Fernandez-Novoa L, Cacabelos R. A novel mutation in the predicted TM2 domain of the presenilin 2 gene in a Spanish patient with late-onset Alzheimer's disease. Neurogenetics 1998; 1: 293-6.

97. Zekanowski C, Styczynska M, Peplonska B, Gabryelewicz T, Religa D, Ilkowski J, Kijanowska-Haladyna B, Kotapka-Minc S, Mikkelsen S, Pfeffer A, Barczak A, Luczywek E, Wasiak B, Chodakowska-Zebrowska M, Gustaw K, Laczkowski J, Sobow T, Kuznicki J, Barcikowska M. Mutations in presenilin 1, presenilin 2 and amyloid precursor protein genes in patients with early-onset Alzheimer's disease in Poland. Exp Neurol 2003; 184: 991-6.

98. Scheuner D, Eckman C, Jensen M, Song X, Citron M, Suzuki N, Bird TD, Hardy J, Hutton M, Kukull W, Larson E, Levy-Lahad E, Viitanen M, Peskind E, Poorkaj P, Schellenberg G, Tanzi R, Wasco W, Lannfelt L, Selkoe D, Younkin S. Secreted amyloid beta-protein similar to that in the senile plaques of Alzheimer's disease is increased in vivo by the presenilin 1 and 2 and APP mutations linked to familial Alzheimer's disease. Nat Med 1996; 2: 864-70.

99. Duff K, Eckman C, Zehr C, Yu X, Prada CM, Perez-tur J, Hutton M, Buee L, Harigaya Y, Yager D, Morgan D, Gordon MN, Holcomb L, Refolo L, Zenk B, Hardy J, Younkin S. Increased amyloid-beta42(43) in brains of mice expressing mutant presenilin 1. Nature 1996; 383: 710-3.

100. Ishii K, Ii K, Hasegawa T, Shoji S, Doi A, Mori H. Increased A beta 42(43)-plaque deposition in early-onset familial Alzheimer's disease brains with the deletion of exon 9 and the missense point mutation (H163R) in the PS-1 gene. Neurosci Lett 1997; 228: 17-20. 
101. Citron M, Westaway D, Xia W, Carlson G, Diehl T, Levesque G, Johnson-Wood K, Lee M, Seubert P, Davis A, Kholodenko D, Motter R, Sherrington R, Perry B, Yao H, Strome R, Lieberburg I, Rommens J, Kim S, Schenk D, Fraser P, St George Hyslop P, Selkoe DJ. Mutant presenilins of Alzheimer's disease increase production of 42-residue amyloid betaprotein in both transfected cells and transgenic mice. Nat Med 1997; 3: 67-72.

102. Murayama O, Tomita T, Nihonmatsu N, Murayama M, Sun X, Honda T, Iwatsubo T, Takashima A. Enhancement of amyloid beta 42 secretion by 28 different presenilin 1 mutations of familial Alzheimer's disease. Neurosci Lett 1999; 265: 61-3.

103. Wolfe MS. When loss is gain: reduced presenilin proteolytic function leads to increased Abeta42/Abeta40. Talking Point on the role of presenilin mutations in Alzheimer disease. EMBO Rep 2007; 8: 136-40.

104. De Strooper B. Loss-of-function presenilin mutations in Alzheimer disease. Talking Point on the role of presenilin mutations in Alzheimer disease. EMBO Rep 2007; 8: 141-6.

105. Baumeister R, Leimer U, Zweckbronner I, Jakubek C, Grunberg J, Haass C. Human presenilin-1, but not familial Alzheimer's disease (FAD) mutants, facilitate Caenorhabditis elegans Notch signalling independently of proteolytic processing. Genes Funct 1997; 1: 14959.

106. Bentahir M, Nyabi O, Verhamme J, Tolia A, Horre K, Wiltfang J, Esselmann H, De Strooper B. Presenilin clinical mutations can affect gamma-secretase activity by different mechanisms. J Neurochem 2006; 96: 732-42.

107. Kumar-Singh S, Theuns J, Van Broeck B, Pirici D, Vennekens K, Corsmit E, Cruts M, Dermaut B, Wang R, Van Broeckhoven C. Mean age-of-onset of familial alzheimer disease caused by presenilin mutations correlates with both increased Abeta42 and decreased Abeta40. Hum Mutat 2006; 27: 686-95.

108. Bartus RT, Dean RL, 3rd, Beer B, Lippa AS. The cholinergic hypothesis of geriatric memory dysfunction. Science 1982; 217: 408-14.

109. Kidd PM. Alzheimer's disease, amnestic mild cognitive impairment, and age-associated memory impairment: current understanding and progress toward integrative prevention. Altern Med Rev 2008; 13: 85-115.

110. Alberts B, Johnson A, Lewis J, al. e. Molecular Biology of the Cell 4 ed. Journal 2002, Pages.

111. Raina P, Santaguida P, Ismaila A, Patterson C, Cowan D, Levine M, Booker L, Oremus M. Effectiveness of cholinesterase inhibitors and memantine for treating dementia: evidence review for a clinical practice guideline. Ann Intern Med 2008; 148: 379-97.

112. Winblad B, Jones RW, Wirth Y, Stoffler A, Mobius HJ. Memantine in moderate to severe Alzheimer's disease: a meta-analysis of randomised clinical trials. Dement Geriatr Cogn Disord 2007; 24: 20-7.

113. Beel AJ, Sanders CR. Substrate specificity of gamma-secretase and other intramembrane proteases. Cell Mol Life Sci 2008; 65: 1311-34.

114. Hemming ML, Elias JE, Gygi SP, Selkoe DJ. Proteomic profiling of gamma-secretase substrates and mapping of substrate requirements. PLoS Biol 2008; 6: e257.

115. Wakabayashi T, De Strooper B. Presenilins: members of the gamma-secretase quartets, but part-time soloists too. Physiology (Bethesda) 2008; 23: 194-204.

116. Marambaud P, Wen PH, Dutt A, Shioi J, Takashima A, Siman R, Robakis NK. A CBP Binding Transcriptional Repressor Produced by the PS1/[epsilon]-Cleavage of N-Cadherin Is Inhibited by PS1 FAD Mutations. Cell 2003; 114: 635-645.

117. Okamoto I, Kawano Y, Murakami D, Sasayama T, Araki N, Miki T, Wong AJ, Saya H. Proteolytic release of CD44 intracellular domain and its role in the CD44 signaling pathway. $J$ Cell Biol 2001; 155: 755-62.

118. Yarden Y, Sliwkowski MX. Untangling the ErbB signalling network. Nat Rev Mol Cell Biol 2001; 2: 127-37.

119. Ni CY, Yuan H, Carpenter G. Role of the ErbB-4 carboxyl terminus in gamma-secretase cleavage. J Biol Chem 2003; 278: 4561-5.

120. Lee HJ, Jung KM, Huang YZ, Bennett LB, Lee JS, Mei L, Kim TW. Presenilin-dependent gamma-secretase-like intramembrane cleavage of ErbB4. J Biol Chem 2002; 277: 6318-23. 
121. Ni CY, Murphy MP, Golde TE, Carpenter G. gamma -Secretase cleavage and nuclear localization of ErbB-4 receptor tyrosine kinase. Science 2001; 294: 2179-81.

122. Fortini ME. Gamma-secretase-mediated proteolysis in cell-surface-receptor signalling. Nat Rev Mol Cell Biol 2002; 3: 673-84.

123. Artavanis-Tsakonas S, Rand MD, Lake RJ. Notch signaling: cell fate control and signal integration in development. Science 1999; 284: 770-6.

124. Sanchez-Irizarry C, Carpenter AC, Weng AP, Pear WS, Aster JC, Blacklow SC. Notch subunit heterodimerization and prevention of ligand-independent proteolytic activation depend, respectively, on a novel domain and the LNR repeats. Mol Cell Biol 2004; 24: 926573.

125. Tousseyn T, Thathiah A, Jorissen E, Raemaekers T, Konietzko U, Reiss K, Maes E, Snellinx A, Serneels L, Nyabi O, Annaert W, Saftig P, Hartmann D, De Strooper B. ADAM10, the rate-limiting protease of regulated intramembrane proteolysis of Notch and other proteins, is processed by ADAMS-9, ADAMS-15, and the gamma-secretase. J Biol Chem 2009; 284: 11738-47.

126. De Strooper B, Annaert W, Cupers P, Saftig P, Craessaerts K, Mumm JS, Schroeter EH, Schrijvers V, Wolfe MS, Ray WJ, Goate A, Kopan R. A presenilin-1-dependent gammasecretase-like protease mediates release of Notch intracellular domain. Nature 1999; 398: $518-22$

127. Mumm JS, Schroeter EH, Saxena MT, Griesemer A, Tian X, Pan DJ, Ray WJ, Kopan R. A ligand-induced extracellular cleavage regulates gamma-secretase-like proteolytic activation of Notch1. Mol Cell 2000; 5: 197-206.

128. Okochi M, Fukumori A, Jiang J, Itoh N, Kimura R, Steiner H, Haass C, Tagami S, Takeda M. Secretion of the Notch-1 Abeta-like peptide during Notch signaling. J Biol Chem 2006; 281 : 7890-8.

129. Okochi M, Steiner H, Fukumori A, Tanii H, Tomita T, Tanaka T, Iwatsubo T, Kudo T, Takeda M, Haass C. Presenilins mediate a dual intramembranous gamma-secretase cleavage of Notch-1. EMBO J 2002; 21: 5408-16.

130. Kimberly WT, Esler WP, Ye W, Ostaszewski BL, Gao J, Diehl T, Selkoe DJ, Wolfe MS. Notch and the amyloid precursor protein are cleaved by similar gamma-secretase(s). Biochemistry 2003; 42: 137-44.

131. Berezovska O, Jack C, Deng A, Gastineau N, Rebeck GW, Hyman BT. Notch1 and amyloid precursor protein are competitive substrates for presenilin1-dependent gamma-secretase cleavage. J Biol Chem 2001; 276: 30018-23.

132. Lleo A, Berezovska O, Ramdya P, Fukumoto H, Raju S, Shah T, Hyman BT. Notch1 competes with the amyloid precursor protein for gamma-secretase and down-regulates presenilin-1 gene expression. J Biol Chem 2003; 278: 47370-5.

133. Shen J, Bronson RT, Chen DF, Xia W, Selkoe DJ, Tonegawa S. Skeletal and CNS defects in Presenilin-1-deficient mice. Cell 1997; 89: 629-39.

134. Herreman A, Hartmann D, Annaert W, Saftig P, Craessaerts K, Serneels L, Umans L, Schrijvers V, Checler F, Vanderstichele H, Baekelandt V, Dressel R, Cupers P, Huylebroeck D, Zwijsen A, Van Leuven F, De Strooper B. Presenilin 2 deficiency causes a mild pulmonary phenotype and no changes in amyloid precursor protein processing but enhances the embryonic lethal phenotype of presenilin 1 deficiency. Proc Natl Acad Sci U S A 1999; 96: 11872-7.

135. Rozmahel R, Huang J, Chen F, Liang Y, Nguyen V, Ikeda M, Levesque G, Yu G, Nishimura M, Mathews P, Schmidt SD, Mercken M, Bergeron C, Westaway D, St George-Hyslop P. Normal brain development in PS1 hypomorphic mice with markedly reduced gammasecretase cleavage of betaAPP. Neurobiol Aging 2002; 23: 187-94.

136. Lai MT, Chen E, Crouthamel MC, DiMuzio-Mower J, Xu M, Huang Q, Price E, Register RB, Shi XP, Donoviel DB, Bernstein A, Hazuda D, Gardell SJ, Li YM. Presenilin-1 and presenilin-2 exhibit distinct yet overlapping gamma-secretase activities. J Biol Chem 2003; 278: 22475-81. 
137. Mastrangelo P, Mathews PM, Chishti MA, Schmidt SD, Gu Y, Yang J, Mazzella MJ, Coomaraswamy J, Horne P, Strome B, Pelly H, Levesque G, Ebeling C, Jiang Y, Nixon RA, Rozmahel R, Fraser PE, St George-Hyslop P, Carlson GA, Westaway D. Dissociated phenotypes in presenilin transgenic mice define functionally distinct gamma-secretases. Proc Natl Acad Sci U S A 2005; 102: 8972-7.

138. Placanica L, Tarassishin L, Yang G, Peethumnongsin E, Kim SH, Zheng H, Sisodia SS, Li YM. Pen2 and presenilin-1 modulate the dynamic equilibrium of presenilin-1 and presenilin-2 gamma-secretase complexes. J Biol Chem 2009; 284: 2967-77.

139. Ma G, Li T, Price DL, Wong PC. APH-1a is the principal mammalian APH-1 isoform present in gamma-secretase complexes during embryonic development. J Neurosci 2005; 25: 192-8.

140. Serneels L, Dejaegere T, Craessaerts K, Horre K, Jorissen E, Tousseyn T, Hebert S, Coolen M, Martens G, Zwijsen A, Annaert W, Hartmann D, De Strooper B. Differential contribution of the three Aph1 genes to gamma-secretase activity in vivo. Proc Natl Acad Sci U S A 2005; 102: 1719-24.

141. Dejaegere T, Serneels L, Schafer MK, Van Biervliet J, Horre K, Depboylu C, Alvarez-Fischer D, Herreman A, Willem M, Haass C, Hoglinger GU, D'Hooge R, De Strooper B. Deficiency of Aph1B/C-gamma-secretase disturbs Nrg1 cleavage and sensorimotor gating that can be reversed with antipsychotic treatment. Proc Natl Acad Sci U S A 2008; 105: 9775-80.

142. Li YM, Xu M, Lai MT, Huang Q, Castro JL, DiMuzio-Mower J, Harrison T, Lellis C, Nadin A, Neduvelil JG, Register RB, Sardana MK, Shearman MS, Smith AL, Shi XP, Yin KC, Shafer JA, Gardell SJ. Photoactivated gamma-secretase inhibitors directed to the active site covalently label presenilin 1. Nature 2000; 405: 689-94.

143. Shearman MS, Beher D, Clarke EE, Lewis HD, Harrison T, Hunt P, Nadin A, Smith AL, Stevenson G, Castro JL. L-685,458, an aspartyl protease transition state mimic, is a potent inhibitor of amyloid beta-protein precursor gamma-secretase activity. Biochemistry 2000; 39: 8698-704.

144. Martys-Zage JL, Kim SH, Berechid B, Bingham SJ, Chu S, Sklar J, Nye J, Sisodia SS. Requirement for presenilin 1 in facilitating lagged 2-mediated endoproteolysis and signaling of Notch 1. J Mol Neurosci 2000; 15: 189-204.

145. Lewis HD, Perez Revuelta BI, Nadin A, Neduvelil JG, Harrison T, Pollack SJ, Shearman MS. Catalytic site-directed gamma-secretase complex inhibitors do not discriminate pharmacologically between Notch S3 and beta-APP cleavages. Biochemistry 2003; 42: 75806.

146. Lammich S, Okochi M, Takeda M, Kaether C, Capell A, Zimmer AK, Edbauer D, Walter J, Steiner H, Haass C. Presenilin-dependent intramembrane proteolysis of CD44 leads to the liberation of its intracellular domain and the secretion of an Abeta-like peptide. $J$ Biol Chem 2002; 277: 44754-9.

147. Haas IG, Frank M, Veron N, Kemler R. Presenilin-dependent processing and nuclear function of gamma-protocadherins. J Biol Chem 2005; 280: 9313-9.

148. Evin G, Sharples RA, Weidemann A, Reinhard FB, Carbone V, Culvenor JG, Holsinger RM, Sernee MF, Beyreuther K, Masters CL. Aspartyl protease inhibitor pepstatin binds to the presenilins of Alzheimer's disease. Biochemistry 2001; 40: 8359-68.

149. Xiong K, Clough RW, Luo XG, Struble RG, Li YM, Yan XX. [3H]-L-685,458 as a radiotracer that maps gamma-secretase complex in the rat brain: relevance to Abeta genesis and presence of active presenilin-1 components. Brain Res 2007; 1157: 81-91.

150. Yao J, Duan L, Fan M, Wu X. Gamma-secretase inhibitors exerts antitumor activity via down-regulation of Notch and Nuclear factor kappa B in human tongue carcinoma cells. Oral Dis 2007; 13: 555-63.

151. De Keersmaecker K. ABL1 fusions in T-cell acute lymphoblastic leukemia. Verh K Acad Geneeskd Belg 2008; 70: 245-55.

152. Dovey HF, John V, Anderson JP, Chen LZ, de Saint Andrieu P, Fang LY, Freedman SB, Folmer B, Goldbach E, Holsztynska EJ, Hu KL, Johnson-Wood KL, Kennedy SL, Kholodenko D, Knops JE, Latimer LH, Lee M, Liao Z, Lieberburg IM, Motter RN, Mutter LC, Nietz J, Quinn KP, Sacchi KL, Seubert PA, Shopp GM, Thorsett ED, Tung JS, Wu J, 
Yang S, Yin CT, Schenk DB, May PC, Altstiel LD, Bender MH, Boggs LN, Britton TC, Clemens JC, Czilli DL, Dieckman-McGinty DK, Droste JJ, Fuson KS, Gitter BD, Hyslop PA, Johnstone EM, Li WY, Little SP, Mabry TE, Miller FD, Audia JE. Functional gammasecretase inhibitors reduce beta-amyloid peptide levels in brain. J Neurochem 2001; 76: 17381.

153. Lanz TA, Himes CS, Pallante G, Adams L, Yamazaki S, Amore B, Merchant KM. The gamma-secretase inhibitor $\mathrm{N}$-[N-(3,5-difluorophenacetyl)-L-alanyl]-S-phenylglycine t-butyl ester reduces A beta levels in vivo in plasma and cerebrospinal fluid in young (plaque-free) and aged (plaque-bearing) Tg2576 mice. J Pharmacol Exp Ther 2003; 305: 864-71.

154. Best JD, Jay MT, Otu F, Ma J, Nadin A, Ellis S, Lewis HD, Pattison C, Reilly M, Harrison T, Shearman MS, Williamson TL, Atack JR. Quantitative measurement of changes in amyloidbeta(40) in the rat brain and cerebrospinal fluid following treatment with the gamma-secretase inhibitor LY-411575 [N2-[(2S)-2-(3,5-difluorophenyl)-2-hydroxyethanoyl]-N1-[(7S)-5methyl-6-oxo-6,7-d ihydro-5H-dibenzo[b,d]azepin-7-yl]-L-alaninamide]. J Pharmacol Exp Ther 2005; 313: 902-8.

155. Siemers E, Skinner M, Dean RA, Gonzales C, Satterwhite J, Farlow M, Ness D, May PC. Safety, tolerability, and changes in amyloid beta concentrations after administration of a gamma-secretase inhibitor in volunteers. Clin Neuropharmacol 2005; 28: 126-32.

156. Siemers ER, Quinn JF, Kaye J, Farlow MR, Porsteinsson A, Tariot P, Zoulnouni P, Galvin JE, Holtzman DM, Knopman DS, Satterwhite J, Gonzales C, Dean RA, May PC. Effects of a gamma-secretase inhibitor in a randomized study of patients with Alzheimer disease. Neurology 2006; 66: 602-4.

157. Searfoss GH, Jordan WH, Calligaro DO, Galbreath EJ, Schirtzinger LM, Berridge BR, Gao H, Higgins MA, May PC, Ryan TP. Adipsin, a biomarker of gastrointestinal toxicity mediated by a functional gamma-secretase inhibitor. J Biol Chem 2003; 278: 46107-16.

158. Wong GT, Manfra D, Poulet FM, Zhang Q, Josien H, Bara T, Engstrom L, Pinzon-Ortiz M, Fine JS, Lee HJ, Zhang L, Higgins GA, Parker EM. Chronic treatment with the gammasecretase inhibitor LY-411,575 inhibits beta-amyloid peptide production and alters lymphopoiesis and intestinal cell differentiation. J Biol Chem 2004; 279: 12876-82.

159. Green RC, Schneider LS, Hendrix SB, Zavitz KH, Swabb E. Safety and efficacy of tarenflurbil in subjects with mild Alzheimer's disease: Results from an 18-month multi-center phase 3 trial Alzheimer's \& Dementia. The Journal of Alzheimer's Association 2008; 4: T165.

160. Wilcock GK, Black SE, Hendrix SB, Zavitz KH, Swabb EA, Laughlin MA. Efficacy and safety of tarenflurbil in mild to moderate Alzheimer's disease: a randomised phase II trial. Lancet Neurol 2008; 7: 483-93.

161. Britschgi M, Wyss-Coray T. Immune cells may fend off Alzheimer disease. Nat Med 2007; 13: 408-9.

162. Netzer WJ, Dou F, Cai D, Veach D, Jean S, Li Y, Bornmann WG, Clarkson B, Xu H, Greengard P. Gleevec inhibits beta-amyloid production but not Notch cleavage. Proc Natl Acad Sci U S A 2003; 100: 12444-9.

163. Fraering PC, Ye W, LaVoie MJ, Ostaszewski BL, Selkoe DJ, Wolfe MS. gamma-Secretase substrate selectivity can be modulated directly via interaction with a nucleotide-binding site. $J$ Biol Chem 2005; 280: 41987-96.

164. Wolfe MS. Gamma-secretase inhibition and modulation for Alzheimer's disease. Curr Alzheimer Res 2008; 5: 158-64.

165. Vassar R, Citron M. Abeta-generating enzymes: recent advances in beta- and gammasecretase research. Neuron 2000; 27: 419-22.

166. Ho A, Sudhof TC. Binding of F-spondin to amyloid-beta precursor protein: a candidate amyloid-beta precursor protein ligand that modulates amyloid-beta precursor protein cleavage. Proc Natl Acad Sci U S A 2004; 101: 2548-53.

167. Araki Y, Miyagi N, Kato N, Yoshida T, Wada S, Nishimura M, Komano H, Yamamoto T, De Strooper B, Yamamoto K, Suzuki T. Coordinated metabolism of Alcadein and amyloid betaprotein precursor regulates FE65-dependent gene transactivation. J Biol Chem 2004; 279: 24343-54. 
168. Walsh DM, Fadeeva JV, LaVoie MJ, Paliga K, Eggert S, Kimberly WT, Wasco W, Selkoe DJ. gamma-Secretase cleavage and binding to FE65 regulate the nuclear translocation of the intracellular C-terminal domain (ICD) of the APP family of proteins. Biochemistry 2003; 42: 6664-73.

169. Eggert S, Paliga K, Soba P, Evin G, Masters CL, Weidemann A, Beyreuther K. The proteolytic processing of the amyloid precursor protein gene family members APLP-1 and APLP-2 involves alpha-, beta-, gamma-, and epsilon-like cleavages: modulation of APLP-1 processing by n-glycosylation. J Biol Chem 2004; 279: 18146-56.

170. Endres K, Postina R, Schroeder A, Mueller U, Fahrenholz F. Shedding of the amyloid precursor protein-like protein APLP2 by disintegrin-metalloproteinases. FEBS $J$ 2005; 272: 5808-20.

171. Hoe HS, Rebeck GW. Regulation of ApoE receptor proteolysis by ligand binding. Brain Res Mol Brain Res 2005; 137: 31-9.

172. May P, Bock HH, Nimpf J, Herz J. Differential glycosylation regulates processing of lipoprotein receptors by gamma-secretase. J Biol Chem 2003; 278: 37386-92.

173. Brown MS, Goldstein JL. The SREBP pathway: regulation of cholesterol metabolism by proteolysis of a membrane-bound transcription factor. Cell 1997; 89: 331-40.

174. Tomita T, Tanaka S, Morohashi Y, Iwatsubo T. Presenilin-dependent intramembrane cleavage of ephrin-B1. Mol Neurodegener 2006; 1: 2.

175. Georgakopoulos A, Litterst C, Ghersi E, Baki L, Xu C, Serban G, Robakis NK. Metalloproteinase/Presenilin1 processing of ephrinB regulates EphB-induced Src phosphorylation and signaling. EMBO J 2006; 25: 1242-52.

176. Litterst C, Georgakopoulos A, Shioi J, Ghersi E, Wisniewski T, Wang R, Ludwig A, Robakis NK. Ligand binding and calcium influx induce distinct ectodomain/gamma-secretaseprocessing pathways of EphB2 receptor. J Biol Chem 2007; 282: 16155-63.

177. Marambaud P, Shioi J, Serban G, Georgakopoulos A, Sarner S, Nagy V, Baki L, Wen P, Efthimiopoulos S, Shao Z, Wisniewski T, Robakis NK. A presenilin-1/gamma-secretase cleavage releases the E-cadherin intracellular domain and regulates disassembly of adherens junctions. EMBO J 2002; 21: 1948-56.

178. Uemura K, Kihara T, Kuzuya A, Okawa K, Nishimoto T, Ninomiya H, Sugimoto H, Kinoshita A, Shimohama S. Characterization of sequential N-cadherin cleavage by ADAM10 and PS1. Neurosci Lett 2006; 402: 278-83.

179. Andersson CX, Fernandez-Rodriguez J, Laos S, Baeckstrom D, Haass C, Hansson GC. Shedding and gamma-secretase-mediated intramembrane proteolysis of the mucin-type molecule CD43. Biochem J 2005; 387: 377-84.

180. Murakami D, Okamoto I, Nagano O, Kawano Y, Tomita T, Iwatsubo T, De Strooper B, Yumoto E, Saya H. Presenilin-dependent gamma-secretase activity mediates the intramembranous cleavage of CD44. Oncogene 2003; 22: 1511-6.

181. Schulte A, Schulz B, Andrzejewski MG, Hundhausen C, Mletzko S, Achilles J, Reiss K, Paliga K, Weber C, John SR, Ludwig A. Sequential processing of the transmembrane chemokines CX3CL1 and CXCL16 by alpha- and gamma-secretases. Biochem Biophys Res Commun 2007; 358: 233-40.

182. Shimizu K, Chiba S, Hosoya N, Kumano K, Saito T, Kurokawa M, Kanda Y, Hamada Y, Hirai H. Binding of Delta1, Jagged1, and Jagged2 to Notch2 rapidly induces cleavage, nuclear translocation, and hyperphosphorylation of Notch2. Mol Cell Biol 2000; 20: 6913-22.

183. Saxena MT, Schroeter EH, Mumm JS, Kopan R. Murine Notch homologs (N1-4) undergo presenilin-dependent proteolysis. J Biol Chem 2001; 276: 40268-73.

184. Mizutani T, Taniguchi Y, Aoki T, Hashimoto N, Honjo T. Conservation of the biochemical mechanisms of signal transduction among mammalian Notch family members. Proc Natl Acad Sci U S A 2001; 98: 9026-31.

185. Wilhelmsen K, van der Geer P. Phorbol 12-myristate 13-acetate-induced release of the colony-stimulating factor 1 receptor cytoplasmic domain into the cytosol involves two separate cleavage events. Mol Cell Biol 2004; 24: 454-64. 
186. Taniguchi Y, Kim SH, Sisodia SS. Presenilin-dependent "gamma-secretase" processing of deleted in colorectal cancer (DCC). J Biol Chem 2003; 278: 30425-8.

187. Kim DY, Ingano LA, Kovacs DM. Nectin-1alpha, an immunoglobulin-like receptor involved in the formation of synapses, is a substrate for presenilin/gamma-secretase-like cleavage. $J$ Biol Chem 2002; 277: 49976-81.

188. Gowrishankar K, Zeidler MG, Vincenz C. Release of a membrane-bound death domain by gamma-secretase processing of the p75NTR homolog NRADD. J Cell Sci 2004; 117: 4099111.

189. Meyer EL, Strutz N, Gahring LC, Rogers SW. Glutamate receptor subunit 3 is modified by site-specific limited proteolysis including cleavage by gamma-secretase. J Biol Chem 2003; 278: 23786-96.

190. LaVoie MJ, Selkoe DJ. The Notch ligands, Jagged and Delta, are sequentially processed by alpha-secretase and presenilin/gamma-secretase and release signaling fragments. J Biol Chem 2003; 278: 34427-37.

191. Ikeuchi T, Sisodia SS. The Notch ligands, Delta1 and Jagged2, are substrates for presenilindependent "gamma-secretase" cleavage. J Biol Chem 2003; 278: 7751-4.

192. von Arnim CA, Kinoshita A, Peltan ID, Tangredi MM, Herl L, Lee BM, Spoelgen R, Hshieh TT, Ranganathan S, Battey FD, Liu CX, Bacskai BJ, Sever S, Irizarry MC, Strickland DK, Hyman BT. The low density lipoprotein receptor-related protein (LRP) is a novel betasecretase (BACE1) substrate. J Biol Chem 2005; 280: 17777-85.

193. Zou Z, Chung B, Nguyen T, Mentone S, Thomson B, Biemesderfer D. Linking receptormediated endocytosis and cell signaling: evidence for regulated intramembrane proteolysis of megalin in proximal tubule. J Biol Chem 2004; 279: 34302-10.

194. Mi K, Johnson GV. Regulated proteolytic processing of LRP6 results in release of its intracellular domain. $J$ Neurochem 2007; 101: 517-29.

195. Kuhn PH, Marjaux E, Imhof A, De Strooper B, Haass C, Lichtenthaler SF. Regulated intramembrane proteolysis of the interleukin-1 receptor II by alpha-, beta-, and gammasecretase. J Biol Chem 2007; 282: 11982-95.

196. Urra S, Escudero CA, Ramos P, Lisbona F, Allende E, Covarrubias P, Parraguez JI, Zampieri N, Chao MV, Annaert W, Bronfman FC. TrkA receptor activation by nerve growth factor induces shedding of the p75 neurotrophin receptor followed by endosomal gamma-secretasemediated release of the p75 intracellular domain. J Biol Chem 2007; 282: 7606-15.

197. Cowan JW, Wang X, Guan R, He K, Jiang J, Baumann G, Black RA, Wolfe MS, Frank SJ. Growth hormone receptor is a target for presenilin-dependent gamma-secretase cleavage. $J$ Biol Chem 2005; 280: 19331-42.

198. Nyborg AC, Ladd TB, Zwizinski CW, Lah JJ, Golde TE. Sortilin, SorCS1b, and SorLA Vps10p sorting receptors, are novel gamma-secretase substrates. Mol Neurodegener 2006; 1 : 3.

199. Hampe W, Riedel IB, Lintzel J, Bader CO, Franke I, Schaller HC. Ectodomain shedding, translocation and synthesis of SorLA are stimulated by its ligand head activator. J Cell Sci 2000; 113 Pt 24: 4475-85.

200. Wang R, Tang P, Wang P, Boissy RE, Zheng H. Regulation of tyrosinase trafficking and processing by presenilins: partial loss of function by familial Alzheimer's disease mutation. Proc Natl Acad Sci U S A 2006; 103: 353-8.

201. Schulz JG, Annaert W, Vandekerckhove J, Zimmermann P, De Strooper B, David G. Syndecan 3 intramembrane proteolysis is presenilin/gamma-secretase-dependent and modulates cytosolic signaling. J Biol Chem 2003; 278: 48651-7.

202. Wong HK, Sakurai T, Oyama F, Kaneko K, Wada K, Miyazaki H, Kurosawa M, De Strooper B, Saftig P, Nukina N. beta Subunits of voltage-gated sodium channels are novel substrates of beta-site amyloid precursor protein-cleaving enzyme (BACE1) and gamma-secretase. J Biol Chem 2005; 280: 23009-17.

203. Hiesberger T, Gourley E, Erickson A, Koulen P, Ward CJ, Masyuk TV, Larusso NF, Harris PC, Igarashi P. Proteolytic cleavage and nuclear translocation of fibrocystin is regulated by intracellular Ca2+ and activation of protein kinase C. J Biol Chem 2006; 281: 34357-64. 
204. Haapasalo A, Kim DY, Carey BW, Turunen MK, Pettingell WH, Kovacs DM. Presenilin/gamma-secretase-mediated cleavage regulates association of leukocyte-common antigen-related (LAR) receptor tyrosine phosphatase with beta-catenin. J Biol Chem 2007; 282: 9063-72.

205. Carey BW, Kim DY, Kovacs DM. Presenilin/gamma-secretase and alpha-secretase-like peptidases cleave human MHC Class I proteins. Biochem J 2007; 401: 121-7.

206. Kasuga K, Kaneko H, Nishizawa M, Onodera O, Ikeuchi T. Generation of intracellular domain of insulin receptor tyrosine kinase by gamma-secretase. Biochem Biophys Res Commun 2007; 360: 90-6.

207. Maretzky T, Schulte M, Ludwig A, Rose-John S, Blobel C, Hartmann D, Altevogt P, Saftig P, Reiss K. L1 is sequentially processed by two differently activated metalloproteases and presenilin/gamma-secretase and regulates neural cell adhesion, cell migration, and neurite outgrowth. Mol Cell Biol 2005; 25: 9040-53.

208. Bonn S, Seeburg PH, Schwarz MK. Combinatorial expression of alpha- and gammaprotocadherins alters their presenilin-dependent processing. Mol Cell Biol 2007; 27: 4121-32.

209. Anders L, Mertins P, Lammich S, Murgia M, Hartmann D, Saftig P, Haass C, Ullrich A. Furin-, ADAM 10-, and gamma-secretase-mediated cleavage of a receptor tyrosine phosphatase and regulation of beta-catenin's transcriptional activity. Mol Cell Biol 2006; 26: 3917-34.

210. Cai J, Jiang WG, Grant MB, Boulton M. Pigment epithelium-derived factor inhibits angiogenesis via regulated intracellular proteolysis of vascular endothelial growth factor receptor 1. J Biol Chem 2006; 281: 3604-13.

211. Dyczynska E, Sun D, Yi H, Sehara-Fujisawa A, Blobel CP, Zolkiewska A. Proteolytic processing of delta-like 1 by ADAM proteases. J Biol Chem 2007; 282: 436-44.

212. McElroy B, Powell JC, McCarthy JV. The insulin-like growth factor 1 (IGF-1) receptor is a substrate for gamma-secretase-mediated intramembrane proteolysis. Biochem Biophys Res Commun 2007; 358: 1136-41.

213. Saleh AZ, Fang AT, Arch AE, Neupane D, El Fiky A, Krolewski JJ. Regulated proteolysis of the IFNaR2 subunit of the interferon-alpha receptor. Oncogene 2004; 23: 7076-86.

214. Liu CX, Ranganathan S, Robinson S, Strickland DK. gamma-Secretase-mediated release of the low density lipoprotein receptor-related protein 1B intracellular domain suppresses anchorage-independent growth of neuroglioma cells. J Biol Chem 2007; 282: 7504-11. 


\section{Figure Legends}

Figure 1: Proteolytic processing of APP: A schematic of the (A) non-amyloidogenic and (B) amyloidogenic proteolytic processing pathways. (A) In the non-amyloidogenic pathway APP is cleaved by a-secretase (ADAM10/TACE) liberating an APP-C-terminal fragment (C83) that remains embedded in the membrane and a soluble $\alpha$-APPs fragment that is secreted. The C83 fragment is then cleaved into a non-amyloidogenic fragment p3. An APP intracellular domain (AICD) is also formed which translocates to the nucleus and activating gene transcription. (B) In the amyloidogenic pathway, the APP molecule is cleaved by BACE liberating the APP-C99 fragment that remains embedded in the membrane and a secreted truncated form of APPs called $\beta$-APPs. The C99 fragment is cleaved by $\gamma$-secretase generating $A \beta$ fragments, of which $A \beta 40$ and $A \beta 42$ are the major species, and the AICD. (Modified from ${ }^{58}$ )

Figure 2: Sequential cleavage model of APP: In this model, APP-C99 undergoes a number of sequential cleavage events to generate $A \beta 40$ and $A \beta 42$. It is still unclear on whether a single $\gamma$-secretase enzyme or multiple enzymes cleaves the fragments at the particular cleavage sites. The C99 fragment is first cleaved at the e-site to generate an A $\beta 49$ fragment and liberating the AICD. The A $\beta 49$ fragment then undergoes cleavage at the z-site to generate $A \beta 46$. This is the parent fragment which then undergoes cleavage at the g-sites; $A \beta 43$ which can undergo further processing to $A \beta 40$ or $A \beta 42$, which can undergo further cleavage to $A \beta 38 / 39$. (Modified from ${ }^{13}$ ).

Figure 3: Proteolytic processing of Notch: During maturation, the Notch receptor is first cleaved by a furin like protease, at the S1 site of the extracellular domain resulting in two fragments, the Notch extracellular domain (NECD) and the transmembrane domain (NTM) which are held together by a hetero-dimerisation domain (HD). Upon interaction with its ligand, the metalloprotease, ADAM cleaves at the S2 site of extracellular domain of the Notch receptor. Following cleavage at the S2 site, the NTM then undergoes proteolysis at the 
S3/S4 sites by $\gamma$-secretase, liberating the Notch intracellular domain (NICD), which then translocates to the nucleus and activates target gene expression. The S3 cleavage site occurs at the interface between the cytosol and membrane liberating the NICD. The S4 cleavage site near the middle of the transmembrane domain has been shown to liberate the $\mathrm{N} \beta$ fragment. 